\title{
Oyster Mortality Studies In Virginia. II. The Fungus Disease Caused By Dermocystidium Marinum In Oysters Of Chesapeake Bay
}

Jay D. Andrews

Virginia Fisheries Laboratory

Willis G. Hewatt

Follow this and additional works at: https://scholarworks.wm.edu/vimsarticles

Part of the Aquaculture and Fisheries Commons, and the Marine Biology Commons

\section{Recommended Citation}

Andrews, Jay D. and Hewatt, Willis G., Oyster Mortality Studies In Virginia. II. The Fungus Disease Caused By Dermocystidium Marinum In Oysters Of Chesapeake Bay (1957). Ecological Monographs, 27(1), 1-25. $10.2307 / 1948568$ 


\title{
OYSTER MORTALITY STUDIES IN VIRGINIA. II. THE FUNGUS DISEASE CAUSED BY DERMOCYSTIDIUM MARINUM IN OYSTERS OF CHESAPEAKE BAY*
}

\author{
JAY D. ANDREWS \\ Virginia Fisheries Laboratory, Gloucester Point \\ AND \\ Willis G. HEWATT \\ Texas Christian University, Fort Worth
}

TABLE OF CONTENTS

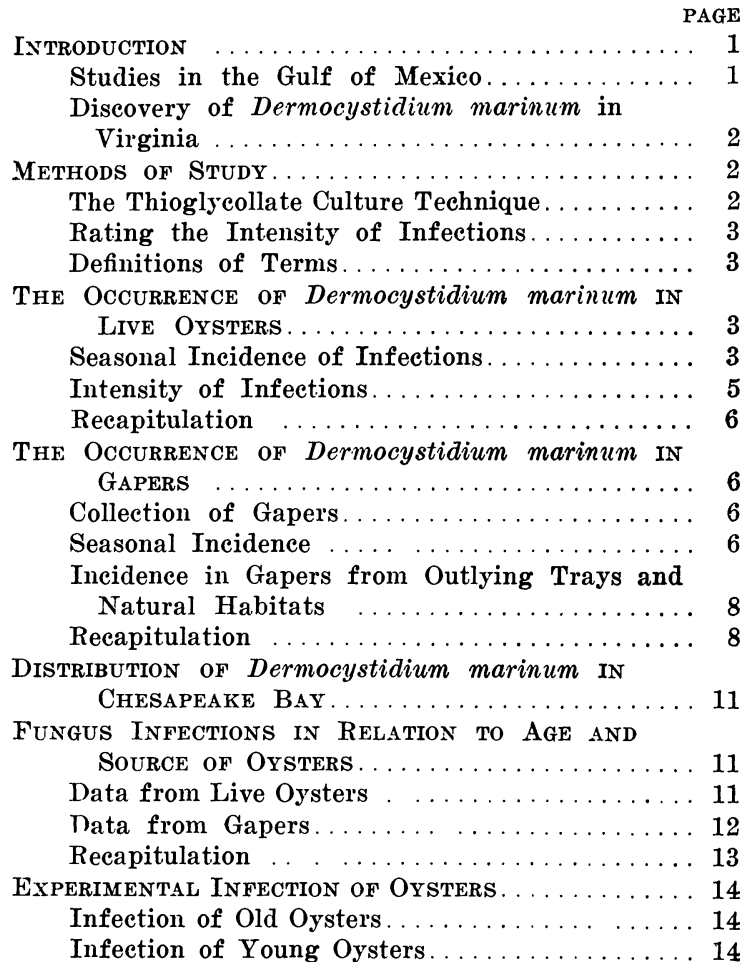

\section{INTRODUCTION}

A high death rate of oysters in Virginia waters during the warm months of summer and fall was reported by Hewatt \& Andrews (1954b). One of the most important causes of this warm-season mortality is the fungus Dermocystidium marinum, a pathogen discovered in the Gulf of Mexico by Mackin, Owen \& Collier (1950). The fungus is found along the coast of the Western Atlantic from Delaware Bay to Florida and on the coast of the Gulf of Mexico from Florida to Texas.

In Chesapeake Bay the disease was studied for pathogenicity to oysters, seasonal occurrence, distribution, and its effect on the oyster industry. Over 3000 dead or dying oysters and 7000 live oysters were examined. Most of the dead or dying oysters

*Contributions from the Virginia Fishëries Laboratory, No. 69 .
Cross-Infection Experiments with Other PAGE Bivalves .................. 15

The Effects of Temperature on Fungus

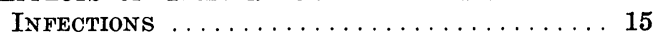

Seasonal and Geographical Effects......... 15

Overwintering of the Fungus in Live Oysters. . . 16

Experimental Infection of Oysters at Various

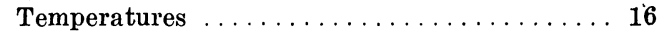

Recapitulation $\ldots \ldots \ldots \ldots \ldots \ldots \ldots \ldots \ldots \ldots$

The Relationship of Salinity and Fungus

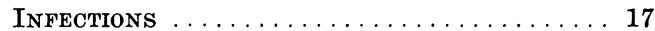

Range of the Fungus and Isohalines........ 17

Effects of Low Salinity on Infections....... 18

Recapitulation ..................... 19

The EfFects of Handling of Oysters and Other Factors on Fungus Infections.......... 19

Effects of Handling on Fungus Infections. . . . . 19

Viability of Fungus Spores...........20

Recapitulation .................. 20

Discussion and Conclusions............ 20

The Importance of Dermocystidium marinum as a Cause of Oyster Disease............. 20

Dissemination of Fungus Spores and Relation to Salinities ...................21

Variations of Infections with Age and Source of Oysters...................22

Effects of the Disease on the Oyster Industry in Chesapeake Bay... ...............22

The Role of Other Parasites and Pests...... 23 Summary $\ldots \ldots \ldots \ldots \ldots \ldots \ldots \ldots \ldots \ldots \ldots . \ldots \ldots$

Literatcre Cited ................. 25

were obtained from trays suspended in the York River at Gloucester Point, Virginia, but the live oysters came from many localities in Chesapeake Bay.

The authors wish to express their appreciation to many colleagues, particularly Dr. J. G. Mackin, Dr. Sammy M. Ray, Dr. Sewell H. Hopkins, and Dexter Haven for continuous aid and friendly criticism throughout the period of this study. The help of many oystermen has been invaluable in obtaining samples of oysters from numerous areas of Chesapeake Bay. The loyal support of several laboratory assistants has aided materially in the investigation.

\section{Studies in the Gulf of Mexico}

The most exhaustive studies of the fungus have been made in Louisiana waters by Mackin (1951, 1953, 1956), Mackin \& Boswell (1956), Ray (1954a, b, c), Ray \& Chandler (1955), and Ray, Mrckin \& 
Boswell (1953). They have shown that the disease is a major cause of warm-season mortalities in the Gulf and that its effects are most serious in highsalinity waters. In Louisiana, D. marinum is active in oysters throughout the year but the mortality accelerates during the warm seasons. Losses are so great that oystermen try to avoid holding oysters on cultivated grounds during summer periods. The fungus infects oysters through the digestive system and perhaps by direct penetration of gill and mantle membranes. The parasites enter blood cells and are distributed to all parts of the body. They increase in the tissues and blood sinuses by multiple fission and probably cause deaths by lysis of organ tissues and embolism of circulatory passages. The occurrence of massive infections in live oysters and the presence of numerous pockets of lysed tissues has led Mackin to suggest that probably no toxic substances are produced by the fungus.

The presence of fungus eells in nearly all tissues of infected oysters indicates that the disease is systemic (Mackin 1951). The most characteristic cell, spherical with a large vacuole, is an infective spore, released by the disintegration of dead oysters, and dispersed by water currents (Mackin \& Boswell 1955). Ray (1954b, e) demonstrated that healthy oysters become infected when they are fed minced tissues from diseased oysters or when the infective material is injected into the mantle cavity.

Mackin (1951) demonstrated the lethality of the disease by histopathological studies of dying oysters. Stained sections of tissues from gapers (dead or dying oysters unable to close their valves) showed fungus cells in large lesions, which indicated gross injury to vital organs. No organism other than Dermocystidium was associated with these lesions.

The pathogenicity of the fungus was determined by comparing the incidence of infections in gapers and live oysters (Mackin 1953). Mackin found light infections most numerous in live oysters whereas heavy infections were predominant in gapers. Since many cases ended in death, he concluded that the disease is highly pathogenic to oysters in the Gulf of Mexico. Eliminating doubtful eases, he stated that death could be attributed to Dermocystidium in about 85 per cent of the gapers collected from five stations in Barataria Bay, Louisiana.

\section{DISCOVERY OF Dermocystidium marinum IN VIRGINIA WATERS}

In the late summer of 1949 , before Mackin, Owe! \& Collier (1950) reported the fungus disease, a severe mortality of oysters occurred in the Rappahannock River. Histological sections of survivors revealed for the first time the presence of the fungus in Virginia (Mackin 1951).

By 1950, a syndrome for the disease had still not been established and recognition depended maindy upon the study of histological sections. At a conference on pathology of oysters, held at Pensacola, Florida, in January 1950, attempts were made to demonstrate the live fungus cells, but since these are easily confused with leucocytes of the oyster, identification" in fresh preparations was precarious. The preparation of histological sections of each oyster was a task which discouraged ecological studies of Dermocystidium in Chesapeake Bay.

Studies of the mortality of oysters held in trays at Gloucester Point in the York River were begun, however, in June 1950 (Hewatt \& Andrews 1954b). The histories of trays of oysters studied subsequent to the first report are given in Table 1. In the sum-

TABLE 1. Histories of oysters grown in trays at Gloucester Point, York River, Virginia.

\begin{tabular}{|c|c|c|c|c|}
\hline $\begin{array}{l}\text { Tray } \\
\text { nos. }\end{array}$ & Source & $\begin{array}{l}\text { Year- } \\
\text { class }\end{array}$ & $\begin{array}{c}\text { Date } \\
\text { transplanted }\end{array}$ & $\begin{array}{c}\text { Original } \\
\text { count }\end{array}$ \\
\hline 15 & Seaside of Eastern Shore & 1952 & $20 \mathrm{Jul} \quad 52$ & 141 \\
\hline 16 & Rappahannock River & 1951 & 31 Oct 52 & 247 \\
\hline 17 to 20 & James River & $1950-51$ & 30 Apr 53 & 800 \\
\hline 21 to 24 & Rappahannock River & market & 7 May 53 & 495 \\
\hline 25 & Rappahannock River & 1952 & 29 Oct 52 & 184 \\
\hline 26 & Corrotoman River & 1952 & 29 Oct 52 & 714 \\
\hline 33 & York River & 1952 & native & 172 \\
\hline 37 & James River & 1952 & 12 Nov 52 & 350 \\
\hline 38 & South Carolina & 1953 & 28 Nov 53 & 350 \\
\hline 39 & Chincoteague Bay & 1953 & 16 Nov 53 & 315 \\
\hline 10 & York River & 1953 & native & 293 \\
\hline 41 & James River & 1952 & 14 Jun 54 & 250 \\
\hline 56 to 61 & Rappaharnock River & market & 1 Jun 55 & 1035 \\
\hline
\end{tabular}

mer of 1950, the preserved meats of twelve gapers from trays were sent to Mackin. He reported (personal communication) that nine of the twelve oysters were heavily infected with the fungus. The presence of Dermocystidium in Virginia waters was estimated, but detailed studies of the disease were begun only after a simple diagnostic technique was developed.

\section{METHODS OF STUDY}

\section{The Thioglycollate Culture Technique}

In the winter of 1951-52, while attempting to culture Dermocystidium, Ray (1952a) discovered a simple technique for detecting the organism in oyster tissue. The method consists of placing pieces of tissue in a fluid thioglycollate medium, which has been fortified with antibiotics to suppress bacterial growth. In the medium, fungus cells enlarge and develop walls which stain blue with Lugol's iodine solution. Cultures are held 48 hours or longer at room temperature before the tissues are examined. Since infections are systemic, any tissue of an oyster may be used for culture.

In our studies, Ray's modified technique (1952b) was used in all tests for the fungus. From each oyster, pieces of gill, mantle, and rectum were cultured in the same test tube. In gapers eroded by scavengers other tissues were substituted. Tissues were usually held in the medium for 48 hours before they were examined. When infections were very light it was found that the fungus was more easily letected if tissues were held in cultures for longer periods, permitting greater enlargement of the fungus cells. The tissues were examined under the low 
power of a compound microseope (60X). Most gapers were obtained from the trays before deterioration had ensued but some were eroded or decayed. A few meats in the last stages of disintegration gave unsatisfactory tests because ratings of the intensity of infection could not be made.

\section{Rating the Intensity of InfeCtions}

In rating the intensity of fungus infections in tissues, the categories defined by Ray, Mackin \& Boswell (1953) were employed. An infection was considered "light" if less than 10 fungus cells were found per microscopic field. "Moderate" infections had numerous parasitic cells in all fields. "Heavy" infections contained high concentrations of fungus cells throughout the cultured tissues, and the blueblack color could easily be seen macroseopically. Sub-categories were used in recording infections, but these have been grouped in the three major categories.

To combine incidence and intensity of infections for comparison of one group of oysters with another, a value termed "weighted incidence," first used by Mackin (Ray 1954a), was employed. The intensity eategories of negative, light, moderate, and heavy infection were assigned, respectively, the arbitrary values of $0,1,3$, and 5 . The weighted incidence is obtained by adding all of the intensity values for a group of oysters and dividing by the total number tested. For example, a weighted incidence of 1.0 indicates that the average infection in the group was light; a value of 3.0 indicates that the infection level was moderate; and a value of 5.0 denotes that all oysters were heavily infected.

\section{Definition of Terms}

Although the fungus is certainly endemic in Chesapeake Bay, the infested area probably varies from year to year with hydrographic and climatic conditions. In this report, it has been necessary to distinguish between disease-infested and disease-free areas. The term "infested" will be used to describe areas where the disease is endemic without connoting characteristics other than the presence of the disease. Oysters from "infested" and "free" areas, which terms refer to either the fungus or the disease, are distinguished, and it has also been necessary to discriminate between oysters acclimated to areas where the fungus is endemic and those recently moved into areas of infestation. Oysters are considered fully acclimated when they have spent at least one warm season in an infested area.

"Native" oysters are those which have set anj grown in one locality. "Transplants" are oysters obtained from a seed area and planted in another locality.

\section{THE OCCURRENCE OF DERMOCYSTIDIUM MARINUM IN LIVE OYSTERS}

In the summer and fall of 1952, groups of live oysters from various localities were tested to de- termine the distribution of the fungus in Chesapeake Bay. It soon became obvious that an intelligent evaluation of the results would require a knowledge of the seasonal pattern of infections. In 1953, therefore, two large groups of oysters were placed in trays at Gloucester Point to provide samples of live oysters for monthly testing. In addition, monthly tests of live oysters from three natural areas were begun. For two or more years, estimates of the incidence and intensity of infections were obtained for each of these five series of oysters.

The first of the five series, Trays 17 to 20, contained oysters moved from Wreck Shoal in the James River, a disease-free area, to Gloucester Point in the York River. The second series, Trays 21 to 24, consisted of oysters moved from Hoghouse Bar in the Rappahannock River to Gloucester Point, both infested areas. The third series, Hoghouse Bar natives, was dredged or tonged each month from publie grounds of the Rappahannock River, an area of low intensity of disease. The fourth series, Hampton Bar transplants, was taken monthly from plantings of James River seed on private grounds in Hampton Roads where the disease is present. The fifth series, Gloucester Point natives, was colleeted from pilings and the bottom around pilings at Gloucester Point, an infested area.

To understand the variations in fungus infections, it is important that the history of oysters be known, particularly as to age, source, and length of time exposed in areas where the disease is endemic. All the oysters in the series were of market size (three or more inches in length) except those in Trays 17 to 20 , which were two and three years old and near market size. The usual sample for estimating incidence and intensity of the fungus was 25 oysters, but as few as 17 and as many as 60 oysters were tested at various times.

\section{Seasonal Incidence of Infections}

The seasonal progression of the disease for each series of oysters is shown in Table 2. In May, at the beginning of the experiment, no infections were found. In oysters acclimated to infested areas, infections appeared in June, increased rapidly during the hot months, remained at a high level from September through November, and gradually declined with the advent of cold weather in December. By the following March or April most infections had disappeared. This pattern of infection was similar in all five series of live oysters during the two years of monthly tests. Additional data for the years 1955 and 1956 amply confirm this seasonal pattern of infections.

In acclimated oysters two years of age and older, at least $70 \%$ became infected each summer and fall, and infections in older oysters often exceeded $90 \%$. At Gloucester Point the incidence of infections was similar in oysters from trays and natural habitats. Oysters from Hampton Bar had incidences similar to those at Gloucester Point but Hoghouse oysters 
TABLE 2. Monthly tests of $D$. marinum in live oysters.

\begin{tabular}{|c|c|c|c|c|c|c|c|c|}
\hline \multirow{2}{*}{ Series } & \multirow[b]{2}{*}{ 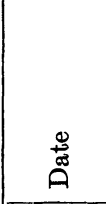 } & \multirow[b]{2}{*}{ 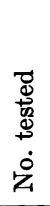 } & \multicolumn{5}{|c|}{ Per cent Infections } & \multirow[b]{2}{*}{ 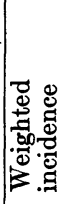 } \\
\hline & & & 密 & 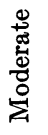 & 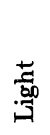 & 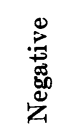 & & \\
\hline \multirow[t]{3}{*}{$\begin{array}{l}\text { 1. Trays } 17 \text { to } 20 \text {, } \\
\text { oysters trans- } \\
\text { planted in April } \\
1953 \text { from a dis- } \\
\text { ease-free to an } \\
\text { infested area. }\end{array}$} & $\begin{array}{rl}1953 \\
30 & \text { Apr } \\
10 & \mathrm{Jun} \\
4 & \mathrm{Jul} \\
3 & \text { Aug } \\
31 & \text { Aug } \\
1 & \text { Oct } \\
3 & \text { Nov } \\
30 & \text { Nov } \\
30 & \text { Dec }\end{array}$ & $\begin{array}{l}25 \\
25 \\
25 \\
25 \\
25 \\
25 \\
25 \\
25 \\
25\end{array}$ & $\begin{array}{l}0 \\
0 \\
0 \\
0 \\
0 \\
4 \\
0 \\
0 \\
4\end{array}$ & $\begin{array}{l}0 \\
0 \\
0 \\
0 \\
4 \\
8 \\
8 \\
0 \\
4\end{array}$ & $\begin{array}{r}0 \\
0 \\
0 \\
8 \\
12 \\
16 \\
48 \\
36 \\
20\end{array}$ & $\begin{array}{r}100 \\
100 \\
100 \\
92 \\
84 \\
72 \\
44 \\
64 \\
72\end{array}$ & $\begin{array}{r}0 \\
0 \\
0 \\
8 \\
16 \\
28 \\
56 \\
36 \\
28\end{array}$ & $\begin{array}{l}0.00 \\
0.00 \\
0.00 \\
0.08 \\
0.24 \\
0.60 \\
0.72 \\
0.36 \\
0.52\end{array}$ \\
\hline & \begin{tabular}{rl}
\multicolumn{1}{c}{1954} \\
29 & $\mathrm{Jan}$ \\
2 & $\mathrm{Mar}$ \\
30 & $\mathrm{Mar}$ \\
3 & $\mathrm{May}$ \\
1 & $\mathrm{Jun}$ \\
1 & $\mathrm{Jul}$ \\
30 & $\mathrm{Jul}$ \\
27 & Aug \\
5 & Oct \\
2 & Nov \\
30 & Nov
\end{tabular} & $\begin{array}{l}25 \\
25 \\
25 \\
25 \\
25 \\
25 \\
25 \\
25 \\
25 \\
25 \\
20\end{array}$ & $\begin{array}{r}0 \\
0 \\
0 \\
0 \\
0 \\
8 \\
0 \\
16 \\
12 \\
4 \\
5\end{array}$ & $\begin{array}{r}4 \\
0 \\
0 \\
0 \\
4 \\
20 \\
12 \\
28 \\
48 \\
28 \\
5\end{array}$ & $\begin{array}{r}8 \\
0 \\
0 \\
0 \\
12 \\
12 \\
56 \\
44 \\
36 \\
60 \\
60\end{array}$ & $\begin{array}{r}88 \\
100 \\
100 \\
100 \\
84 \\
60 \\
32 \\
12 \\
4 \\
8 \\
30\end{array}$ & \begin{tabular}{r|r}
12 & \\
0 & \\
0 & \\
0 & \\
16 & \\
40 & \\
68 & \\
88 & \\
96 & \\
92 & \\
70 &
\end{tabular} & $\begin{array}{l}0.20 \\
0.00 \\
0.00 \\
0.00 \\
0.24 \\
1.12 \\
0.92 \\
2.08 \\
2.40 \\
1.64 \\
1.00\end{array}$ \\
\hline & $\begin{array}{l}1955 \\
4 \text { Jan } \\
3 \text { Feb }\end{array}$ & $\begin{array}{l}17 \\
18\end{array}$ & $\begin{array}{l}\mathbf{0} \\
\mathbf{0}\end{array}$ & $\begin{array}{r}6 \\
11\end{array}$ & $\begin{array}{l}41 \\
17\end{array}$ & $\begin{array}{l}53 \\
72\end{array}$ & & $\begin{array}{l}0.59 \\
0.50\end{array}$ \\
\hline \multirow[t]{2}{*}{$\begin{array}{l}\text { 2. Trays } 21 \text { to } 24, \\
\text { oysters trans- } \\
\text { planted in May } \\
1953 \text { from one } \\
\text { disease-infested } \\
\text { area to another. }\end{array}$} & \begin{aligned} & \multicolumn{1}{|c}{1953} \\
& 7 May \\
& 14 Jul \\
& 4 Aug \\
& 31 Aug \\
& 30 Sep \\
& 29 Oct \\
& 30 Nov \\
& 30 Dec \end{aligned} & $\begin{array}{l}25 \\
25 \\
25 \\
25 \\
25 \\
25 \\
25 \\
25\end{array}$ & $\begin{array}{l}0 \\
0 \\
0 \\
4 \\
4 \\
8 \\
4 \\
4\end{array}$ & $\begin{array}{r}0 \\
12 \\
16 \\
16 \\
20 \\
20 \\
12 \\
16\end{array}$ & $\begin{array}{r}0 \\
4 \\
40 \\
60 \\
52 \\
48 \\
56 \\
40\end{array}$ & $\begin{array}{r}100 \\
84 \\
44 \\
20 \\
24 \\
24 \\
28 \\
40\end{array}$ & $\begin{array}{r}0 \\
16 \\
56 \\
80 \\
76 \\
76 \\
72 \\
60\end{array}$ & $\begin{array}{l}0.00 \\
0.40 \\
0.88 \\
1.28 \\
1.32 \\
1.48 \\
1.12 \\
1.08\end{array}$ \\
\hline & \begin{tabular}{rl}
\multicolumn{1}{c}{1954} \\
29 & $\mathrm{Jan}$ \\
3 & $\mathrm{Mar}$ \\
31 & $\mathrm{Mar}$ \\
3 & $\mathrm{May}$ \\
31 & $\mathrm{May}$ \\
2 & $\mathrm{Jul}$ \\
30 & $\mathrm{Jul}$ \\
28 & Aug \\
1 & Oct
\end{tabular} & $\begin{array}{l}25 \\
25 \\
25 \\
25 \\
25 \\
25 \\
25 \\
25 \\
18\end{array}$ & $\begin{array}{r}0 \\
0 \\
0 \\
0 \\
0 \\
4 \\
0 \\
24 \\
6\end{array}$ & $\begin{array}{r}4 \\
4 \\
0 \\
0 \\
4 \\
16 \\
24 \\
24 \\
39\end{array}$ & $\begin{array}{r}24 \\
4 \\
4 \\
16 \\
28 \\
20 \\
40 \\
44 \\
50\end{array}$ & $\begin{array}{r}72 \\
92 \\
96 \\
84 \\
68 \\
60 \\
36 \\
8 \\
6\end{array}$ & \begin{tabular}{r|l}
28 & \\
8 & \\
4 & 0 \\
16 & \\
32 & 0 \\
40 & 0 \\
64 & 1 \\
92 & \\
94 & 1
\end{tabular} & $\begin{array}{l}0.36 \\
0.16 \\
0.04 \\
0.16 \\
0.40 \\
0.88 \\
1.12 \\
2.36 \\
1.94\end{array}$ \\
\hline \multirow[t]{2}{*}{$\begin{array}{l}\text { 3. Hoghouse Bar } \\
\text { natives dredged } \\
\text { from an infested } \\
\text { area. }\end{array}$} & \begin{tabular}{|rl}
\multicolumn{1}{|c}{1953} \\
7 & May \\
16 & Jun \\
7 & Jul \\
4 & Aug \\
31 & Aug \\
2 & Oct \\
2 & Nov \\
2 & Dec
\end{tabular} & $\begin{array}{l}26 \\
20 \\
52 \\
50 \\
50 \\
50 \\
50 \\
50\end{array}$ & $\begin{array}{l}0 \\
0 \\
2 \\
2 \\
2 \\
2 \\
0 \\
0\end{array}$ & $\begin{array}{r}0 \\
0 \\
4 \\
2 \\
2 \\
2 \\
12 \\
2\end{array}$ & $\begin{array}{r}0 \\
5 \\
4 \\
12 \\
20 \\
30 \\
32 \\
44\end{array}$ & $\begin{array}{r}100 \\
95 \\
92 \\
84 \\
76 \\
66 \\
56 \\
54\end{array}$ & \begin{tabular}{r|l}
0 & \\
5 & \\
8 & \\
16 & \\
24 & \\
34 & ( \\
44 & \\
46 & 0
\end{tabular} & $\begin{array}{l}0.00 \\
0.05 \\
0.25 \\
0.28 \\
0.36 \\
0.46 \\
0.68 \\
0.50\end{array}$ \\
\hline & \begin{tabular}{|rl} 
& 19.54 \\
7 & $\mathrm{Jan}$ \\
2 & $\mathrm{Feb}$ \\
8 & $\mathrm{Mar}$ \\
1 & $\mathrm{Apr}$ \\
12 & $\mathrm{May}$ \\
1 & $\mathrm{Jun}$
\end{tabular} & $\begin{array}{l}25 \\
25 \\
60 \\
40 \\
40 \\
40\end{array}$ & $\begin{array}{l}0 \\
0 \\
0 \\
0 \\
0 \\
0\end{array}$ & $\begin{array}{l}0 \\
0 \\
2 \\
0 \\
0 \\
0\end{array}$ & $\begin{array}{r}12 \\
0 \\
5 \\
2 \\
0 \\
8\end{array}$ & $\begin{array}{r}88 \\
100 \\
93 \\
98 \\
100 \\
93\end{array}$ & \begin{tabular}{r|l}
12 & 0 \\
0 & 0 \\
7 & 0 \\
2 & 0 \\
0 & 0 \\
7 & 0
\end{tabular} & $\begin{array}{l}0.12 \\
0.00 \\
0.10 \\
0.03 \\
0.00 \\
0.08\end{array}$ \\
\hline
\end{tabular}

\begin{tabular}{|c|c|c|c|c|c|c|c|c|}
\hline \multirow[b]{2}{*}{ Series } & \multirow[b]{2}{*}{ 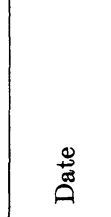 } & \multirow[b]{2}{*}{ 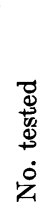 } & \multicolumn{5}{|c|}{ Per cent Infections } & \multirow[b]{2}{*}{ 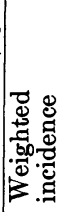 } \\
\hline & & & $\vec{c}$ & 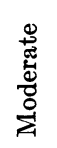 & 苛 & 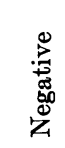 & 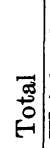 & \\
\hline & $\begin{array}{rl}2 & \mathrm{Jul} \\
28 & \mathrm{Jul} \\
30 & \text { Aug } \\
4 & \text { Oct } \\
29 & \text { Oct }\end{array}$ & $\begin{array}{l}40 \\
40 \\
40 \\
25 \\
25\end{array}$ & $\begin{array}{l}0 \\
0 \\
0 \\
4 \\
4\end{array}$ & $\begin{array}{r}7 \\
10 \\
10 \\
12 \\
16\end{array}$ & $\begin{array}{r}5 \\
12 \\
32 \\
40 \\
52\end{array}$ & $\begin{array}{l}88 \\
78 \\
58 \\
44 \\
28\end{array}$ & $\begin{array}{l}12 \\
22 \\
42 \\
56 \\
72\end{array}$ & $\begin{array}{l}0.28 \\
0.43 \\
0.63 \\
1.20 \\
1.20\end{array}$ \\
\hline & $\begin{array}{rl} & 1955 \\
17 & \mathrm{Jan} \\
1 & \mathrm{Mar} \\
29 & \mathrm{Mar} \\
28 & \mathrm{Apr} \\
2 & \mathrm{Jun} \\
30 & \mathrm{Jun} \\
27 & \mathrm{Jul} \\
26 & \mathrm{Aug} \\
23 & \mathrm{Sep} \\
31 & \text { Oct } \\
1 & \text { Dec }\end{array}$ & $\begin{array}{l}25 \\
25 \\
25 \\
25 \\
25 \\
25 \\
25 \\
25 \\
25 \\
25 \\
25\end{array}$ & $\begin{array}{l}0 \\
0 \\
0 \\
0 \\
0 \\
0 \\
0 \\
8 \\
0 \\
0 \\
0\end{array}$ & $\begin{array}{r}0 \\
0 \\
0 \\
0 \\
0 \\
8 \\
4 \\
20 \\
0 \\
8 \\
4\end{array}$ & $\begin{array}{r}8 \\
0 \\
4 \\
0 \\
0 \\
4 \\
12 \\
52 \\
52 \\
48 \\
40\end{array}$ & $\begin{array}{r}92 \\
100 \\
96 \\
100 \\
100 \\
88 \\
84 \\
20 \\
48 \\
44 \\
56\end{array}$ & $\begin{array}{r}8 \\
0 \\
4 \\
0 \\
0 \\
12 \\
16 \\
80 \\
52 \\
56 \\
44\end{array}$ & $\begin{array}{l}0.08 \\
0.00 \\
0.04 \\
0.00 \\
0.00 \\
0.24 \\
0.24 \\
1.52 \\
0.52 \\
0.72 \\
0.52\end{array}$ \\
\hline \multirow[t]{3}{*}{$\begin{array}{l}\text { 4. Hampton Bar } \\
\text { transplants } \\
\text { tonged from an } \\
\text { infested area. }\end{array}$} & \begin{tabular}{|rl}
\multicolumn{2}{|c}{1953} \\
20 & $\mathrm{Jan}$ \\
15 & $\mathrm{Jul}$ \\
23 & $\mathrm{Jul}$ \\
10 & Aug \\
27 & Aug \\
2 & $\mathrm{Oct}$ \\
2 & Nov \\
2 & Dec
\end{tabular} & $\begin{array}{l}51 \\
25 \\
25 \\
45 \\
50 \\
30 \\
40 \\
40\end{array}$ & $\begin{array}{l}0 \\
4 \\
4 \\
0 \\
0 \\
0 \\
5 \\
2\end{array}$ & $\begin{array}{r}0 \\
16 \\
20 \\
7 \\
12 \\
17 \\
5 \\
2\end{array}$ & $\begin{array}{r}10 \\
8 \\
12 \\
38 \\
36 \\
47 \\
62 \\
40\end{array}$ & $\begin{array}{l}90 \\
72 \\
64 \\
56 \\
52 \\
37 \\
28 \\
55\end{array}$ & $\begin{array}{l}10 \\
28 \\
36 \\
44 \\
48 \\
63 \\
72 \\
45\end{array}$ & $\begin{array}{l}0.10 \\
0.76 \\
0.92 \\
0.58 \\
0.72 \\
0.97 \\
1.03 \\
0.60\end{array}$ \\
\hline & $\begin{aligned} & 1954 \\
6 & \text { Jan } \\
9 & \text { Feb } \\
8 & \text { Mar } \\
3 & \text { Apr } \\
11 & \text { May } \\
3 & \text { Jun } \\
1 & \text { Jul } \\
29 & \text { Jul } \\
27 & \text { Aug } \\
13 & \text { Oct } \\
2 & \text { Nov } \\
10 & \text { Dec }\end{aligned}$ & $\begin{array}{l}40 \\
40 \\
40 \\
40 \\
40 \\
40 \\
40 \\
40 \\
40 \\
25 \\
25 \\
25\end{array}$ & $\begin{array}{r}0 \\
0 \\
0 \\
0 \\
0 \\
0 \\
2 \\
8 \\
12 \\
4 \\
0 \\
0\end{array}$ & $\begin{array}{r}2 \\
2 \\
0 \\
0 \\
0 \\
0 \\
5 \\
10 \\
22 \\
32 \\
28 \\
0\end{array}$ & $\begin{array}{r}32 \\
15 \\
2 \\
0 \\
0 \\
28 \\
20 \\
8 \\
20 \\
52 \\
40 \\
36\end{array}$ & $\begin{array}{r}65 \\
82 \\
98 \\
100 \\
100 \\
72 \\
72 \\
75 \\
45 \\
12 \\
32 \\
64\end{array}$ & $\begin{array}{r}35 \\
18 \\
2 \\
0 \\
0 \\
28 \\
28 \\
25 \\
55 \\
88 \\
68 \\
36\end{array}$ & $\begin{array}{l}0.40 \\
0.23 \\
0.03 \\
0.00 \\
0.00 \\
0.28 \\
0.48 \\
0.75 \\
1.50 \\
1.68 \\
1.24 \\
0.36\end{array}$ \\
\hline & \begin{tabular}{|ll}
\multicolumn{2}{|c}{1955} \\
10 & Feb \\
9 & $\mathrm{Mar}$ \\
2 & $\mathrm{Apr}$ \\
27 & $\mathrm{Apr}$ \\
1 & $\mathrm{Jun}$ \\
30 & $\mathrm{Jun}$ \\
26 & $\mathrm{Jul}$ \\
1 & Sep \\
27 & Sep \\
1 & Nov \\
2 & Dec
\end{tabular} & $\begin{array}{l}25 \\
25 \\
25 \\
25 \\
25 \\
25 \\
25 \\
25 \\
25 \\
25 \\
25\end{array}$ & $\begin{array}{l}0 \\
0 \\
0 \\
0 \\
0 \\
8 \\
8 \\
0 \\
0 \\
0 \\
0\end{array}$ & $\begin{array}{r}0 \\
0 \\
0 \\
0 \\
0 \\
4 \\
12 \\
0 \\
24 \\
28 \\
8\end{array}$ & $\begin{array}{r}24 \\
8 \\
0 \\
4 \\
4 \\
20 \\
28 \\
24 \\
48 \\
52 \\
64\end{array}$ & $\begin{array}{r}76 \\
92 \\
100 \\
96 \\
96 \\
68 \\
52 \\
76 \\
28 \\
20 \\
28\end{array}$ & \begin{tabular}{r|l}
24 & 0 \\
8 & \\
0 & 0 \\
4 & 0 \\
4 & 0 \\
32 & 0 \\
48 & 0 \\
24 & 0 \\
72 & \\
80 & 1 \\
72 & 0
\end{tabular} & $\begin{array}{l}0.24 \\
0.08 \\
0.00 \\
0.04 \\
0.04 \\
0.72 \\
0.84 \\
0.24 \\
1.20 \\
1.36 \\
0.88\end{array}$ \\
\hline \multirow[t]{2}{*}{$\begin{array}{l}\text { 5. Gloucester Point } \\
\text { natives collected } \\
\text { from Ferry Pier } \\
\text { pilings in an } \\
\text { infested area. }\end{array}$} & \begin{aligned} & \multicolumn{1}{c}{1953} \\
& 17 Aug \\
& 27 Aug \\
& 6 Oct \\
& 29 Oct \\
& 1 Dec \\
& 18 Dec \end{aligned} & $\begin{array}{l}50 \\
50 \\
40 \\
25 \\
25 \\
25\end{array}$ & $\begin{array}{l}2 \\
0 \\
5 \\
0 \\
0 \\
0\end{array}$ & $\begin{array}{r}20 \\
20 \\
8 \\
20 \\
20 \\
8\end{array}$ & $\begin{array}{l}30 \\
54 \\
35 \\
36 \\
36 \\
52\end{array}$ & $\begin{array}{l}48 \\
26 \\
52 \\
44 \\
44 \\
40\end{array}$ & \begin{tabular}{l|l}
52 & \\
74 & \\
48 & \\
56 & \\
56 & \\
60 &
\end{tabular} & $\begin{array}{l}1.00 \\
1.14 \\
0.83 \\
0.96 \\
0.96 \\
0.76\end{array}$ \\
\hline & $\begin{array}{l}1954 \\
7 \mathrm{Jan} \\
1 \mathrm{Feb}\end{array}$ & $\begin{array}{l}25 \\
25\end{array}$ & $\begin{array}{l}0 \\
0\end{array}$ & $\begin{array}{l}0 \\
0\end{array}$ & $\begin{array}{l}12 \\
20\end{array}$ & $\begin{array}{l}88 \\
80\end{array}$ & \begin{tabular}{l|l}
12 & 0 \\
20 & 0
\end{tabular} & $\begin{array}{l}0.12 \\
0.20\end{array}$ \\
\hline
\end{tabular}


TABle 2. (Continued)

\begin{tabular}{|c|c|c|c|c|c|c|c|c|}
\hline \multirow{2}{*}{ Series } & \multirow[b]{2}{*}{ 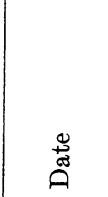 } & \multirow[b]{2}{*}{ 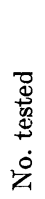 } & \multicolumn{5}{|c|}{ Per cent Infections } & \multirow[b]{2}{*}{ 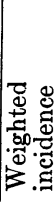 } \\
\hline & & & 胥 & 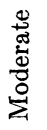 & 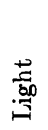 & 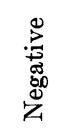 & & \\
\hline & 4 Mar & 25 & 0 & 8 & 16 & 76 & 24 & 0.40 \\
\hline & $7 \mathrm{Apr}$ & 30 & 0 & 0 & 0 & 100 & 0 & 0.08 \\
\hline & 6 May & 25 & 0 & 4 & 16 & 80 & 20 & 0.20 \\
\hline & 3 Jun & 25 & 0 & 16 & 16 & 68 & 32 & 0.64 \\
\hline & 29 Jun & 25 & 4 & 4 & 16 & 76 & 24 & 0.48 \\
\hline & $29 \mathrm{Jul}$ & 25 & 0 & 36 & 28 & 36 & 64 & 1.36 \\
\hline & 26 Aug & 25 & 12 & 36 & 32 & 20 & 80 & 2.00 \\
\hline & 12 Oct & 25 & 4 & 28 & 52 & 16 & 84 & 1.56 \\
\hline & $5 \mathrm{Nov}$ & 25 & 4 & 36 & 48 & 12 & 88 & 1.76 \\
\hline & $30 \mathrm{Nov}$ & 25 & 0 & 8 & 56 & 36 & 64 & 0.80 \\
\hline & 1955 & & & & & & & \\
\hline & 14 Jan & 25 & 0 & 4 & 36 & 60 & & 0.48 \\
\hline & $3 \mathrm{Feb}$ & 25 & 0 & 4 & 16 & 80 & 20 & 0.28 \\
\hline & 2 Mar & 25 & 0 & 0 & 8 & 92 & 8 & 0.08 \\
\hline & 1 Apr & 25 & 0 & 0 & 0 & 100 & & 0.00 \\
\hline & 28 Apr & 25 & 0 & 4 & 0 & 96 & & 0.12 \\
\hline & 2 Jun & 25 & 0 & 0 & 24 & 76 & 24 & 0.24 \\
\hline & 29 Jun & 25 & 0 & 20 & 32 & 48 & 52 & 0.92 \\
\hline & $26 \mathrm{Jul}$ & 25 & 0 & 32 & 32 & 36 & 64 & 1.28 \\
\hline & 29 Aug & 25 & 4 & 24 & 44 & 28 & 72 & 1.36 \\
\hline & 26 Sep & 25 & 4 & 32 & 40 & 24 & 76 & 1.56 \\
\hline & 28 Oct & 25 & 0 & 20 & 72 & 8 & 92 & 1.32 \\
\hline & 1 Dec & 25 & 8 & 12 & 48 & 32 & 68 & 1.12 \\
\hline
\end{tabular}

usually had fewer infections. Fungus infections and mortalities reached higher levels in all groups in 1954 than in 1953 and 1955. In the three series of oysters at Gloucester Point and the series at Hampton Roads, the maximum levels of infection in 1954 ranged from 88 to $96 \%$.

Hoghouse Bar natives, with a maximum of $46 \%$ in 1953 and $72 \%$ in 1954, had the lowest incidence of infections of the five stations during both years. Infections were slow and late in developing at Hoghouse Bar, and a comparatively low level of infection prevailed throughout the summer and fall. Usually in this area the maximum level of infection was not reached before the first of November, and the fiungus appears to be less active than at the other localities studied.

In 1953 infections appeared late also in Trays 17 to 20 (Fig. 1). In this group, moved from a disease-free area in April 1953, only $16 \%$ was infected on August 31. At this time fully-acclimated oysters at Gloucester Point had reached a peak infection for the season of 74 to $80 \%$ (Table 2). The maximum infection of $56 \%$ in Trays 17 to 20 was not reached until November. The late appearance and the low level of infections is typical of oysters recently moved from fungus-free areas. This delay in the development of infections in oysters from fungus-free areas is apparently related to the absence of overwintering infections.

\section{INTENSITY OF INFECTIONS}

Live oysters show more light than moderate infections and more moderate than heary ones (Table

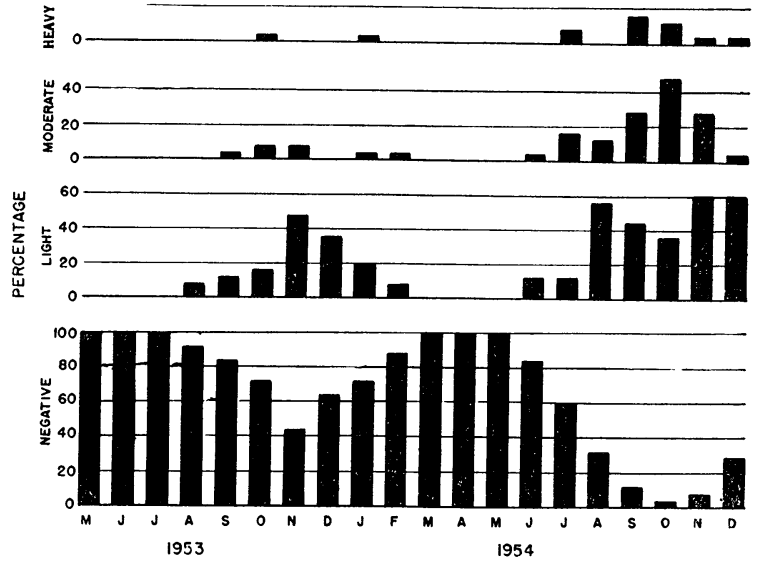

Fig. 1. The seasonal pattern of infection by $D$. marinum found in live oysters from Trays 17 to 20 . Incidence and intensity of infections were determined by monthly samples of 25 oysters. These oysters were moved from a disease-free area to Gloucester Point in April 1953 and were not fully acclimated to this diseaseinfested area in that summer and fall. The late occurrence and low incidence of infections the first summer after transplanting is typical of disease-free oysters in infested areas. The timing and level of infections in 1954 are characteristic of acclimated oysters.

$2 \&$ Fig. 1). This is expected if new infections are occurring, if some infections are becoming progressively heavier, and if oysters with heavy infections are being removed by death. During the early summer the first two of these factors were predominant and the monthly tests showed a rapid rise in the level of infections. During August, September and October each year, 25 to $50 \%$ of the oysters were removed as gapers, and nearly all of these were heavily infected. In the fall, despite the persistent removal of heavy infections, the monthly tests of survivors showed no decline in incidences and intensities. This means that in September and October the intensity of the fungus in survivors was increasing at a rapid rate.

Weighted incidences of infections for the five series reveal that the fungus continued to increase until October or November of each year. Early in November mortalities almost ceased and it appears, therefore, that infections increased only as long as oysters were dying and spores were being released by deterioration of infected gapers. Weighted incidence remained high for almost two months after water temperatures began to drop in September. It is concluded that spores were available and must have been infective at least as late as the first of November.

The weighted incidences were higher in 1954 than in 1953 or 1955 . The percentages of infection in the moderate and heavy categories were considerably greater in 1954, and there were periods when nearly half of the live oysters tested had serious infections. 


\section{RECAPITULATION}

The data from live oysters reveal that in Chesapeake Bay the fungus is abundant in oysters in the warm season and scarce in the cold season. Most oysters become infected each summer and the incidence of infection is equally high in tray-grown and natural oysters at nearly all stations. Oysters recently moved from disease-free areas obtain infections later and have lower incidences the first summer due to the absence of overwintering infections. The intensity of' infections in survivors continues to increase until about November despite the removal of many heavilyinfected gapers.

\section{THE OCCURRENCE OF DERMOCYSTIDIUM MARINUM IN GAPERS}

\section{Collection of Gapers}

In the summers of 1950 and 1951, a few gaping oysters were collected from trays at Gloucester Point. During the years 1952 to 1955 over 3000 gapers from some 30 trays of oysters were tested for the fungus. About $88 \%$ of all dead oysters in the trays were recovered with meats sufficiently intact to permit thioglycollate tests. Most of these gapers were collected during the warm months, and daily examinations of oysters were necessary to recover the meats before they were destroyed by decay organisms and scavengers. Most mud crabs were excluded from the suspended trays, but clingfishes, gobies, and blennies were quick to enter dying oysters and feed on the meats. In winter, few gapers were recovered, and because the trays were examined at 10-day intervals, some of them were in a poor state of preservation.

Gapers were rarely obtained from other areas of Chesapeake Bay. Monthly visits to trays at Darling's watchhouse on Hampton Bar and Sitterding's dock near Hoghouse Bar on the Rappahannock River yielded small numbers. A few dying oysters were collected from dredge boats but it was difficult to distinguish between deaths from natural causes and those induced by dredging operations. Occasionally gapers were collected from pilings where injuries were unlikely to have been the cause of death. The oysters in Trays 17 to 20 and 21 to 24 were transferred to Gloucester Point chiefly because it is difficult to recover gapers in nature. These trays permitted a comparison of fungus infections in live oysters and gapers taken from the same population.

\section{Seasonal Incidence}

Infected gapers have been found in every month of the year. During the summer and fall, large numbers of gapers occurred and the incidence of infection was consistently high. In winter and spring, only a small number of oysters died and the incidence of the disease was lower. Infections found in winter and spring were probably contracted in the summer and fall and the oysters were unable to recover. In Fig. 2, the occurrence of gapers in
Trays 1 to 3 and 6 to 10 during the warm seasons of 1953 and 1954 is shown by 2-day intervals. These oysters were "fully acclimated to the Gloucester Point waters where the disease is endemic, and in June 1953 all had been in trays at the Laboratory pier over 18 months. The beginning of the high-mortality period in June and its ending in November are clearly revealed. The graph also illustrates the incidence and intensity of infections and emphasizes that a great preponderance of gaper infections is in the heavy category. Although a greater proportion of the oysters died in 1954, the distribution of deaths over the season and the incidence and intensity of infections are strikingly similar for the two years.

In Table 3 , the rate of death, the number of gapers tested, and the percentages of infections in each category are given for several groups of trays. Heavily-infected gapers usually appeared in June and continued to occur throughout the warm seasons of summer and fall. For five consecutive months, 80 to $90 \%$ of all gapers had heavy fungus infections, and gapers without infections were rare after July.

Oysters which had not been previously exposed to the disease showed a delay in the appearance of infections and a lower mortality for the first summer (Trays 17 to 20 in 1953). The first infected gapers did not appear until about the first of August, and infections in live oysters appeared for the first time in the monthly tests on August 3. In these oysters, recently transplanted from a disease-free area, the number of deaths was low, but the incidence and intensity of the fungus in gapers were similar to that found in acclimated oysters.

The capacity of the fungus to kill oysters is measured by a comparison of the number and intensity of infections in live oysters and gapers. This, comparison can be made with the data from Trays 17 to 20,21 to 24 (Tables $2 \& 3$ ). A graphic comparison of infections in live oysters and gapers can be seen in Figs. 1 and 2. Most gapers were heavily infected but infections in live oysters usually were light. The weighted incidence for gapers was between 4.0 and 5.0 at a time when the value for live oysters was 1.0 to 2.0. The greater intensity of infections in gapers as compared to live oysters indicates a high level of pathogenicity of the fungus.

Annual variations in incidence and intensity of gaper infections were small (Table 4 and Fig. 2). During the years 1952 to 1955, incidence of infection in gapers varied from 89 to $95 \%$ and the weighted incidence always exceeded 4.0. Most infections were heavy and most of the moderate infections were heavy moderates. We believe that the fungus was the cause of death in nearly all gapers with moderate and heavy infections. Such lethal infections were found in $87 \%$ of the gapers tested during the 4-year period of this study. This emphasizes that in trays the fungus was the primary cause of death of oysters. In 1954 the death rate was exceptionally high because deaths began earlier than 
TABLE 3. Infections of D. marinum in gapers.

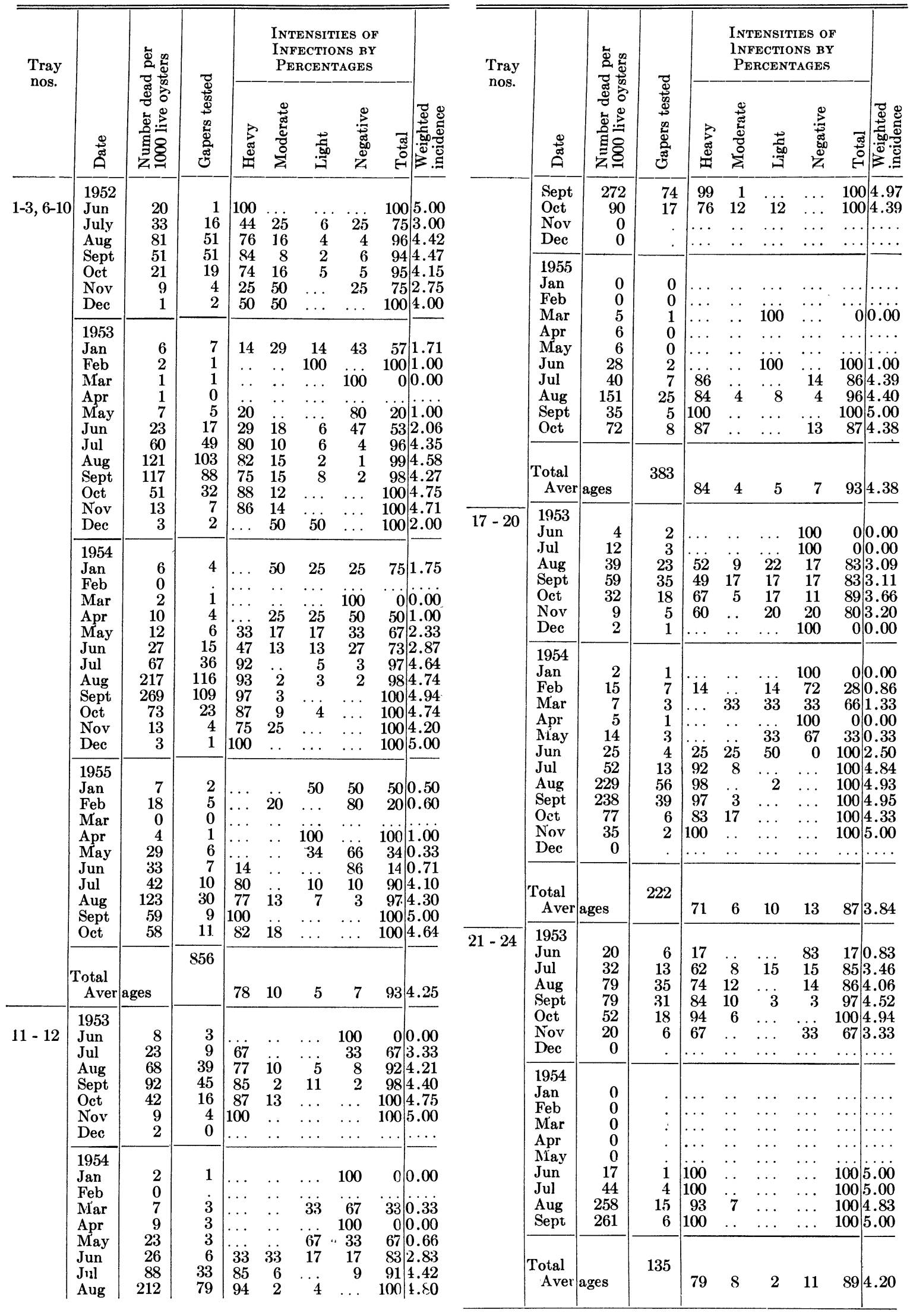


TABLE 4. Fungus infections in gapers from native oysters two years of age or older in trays at Gloucester Point.

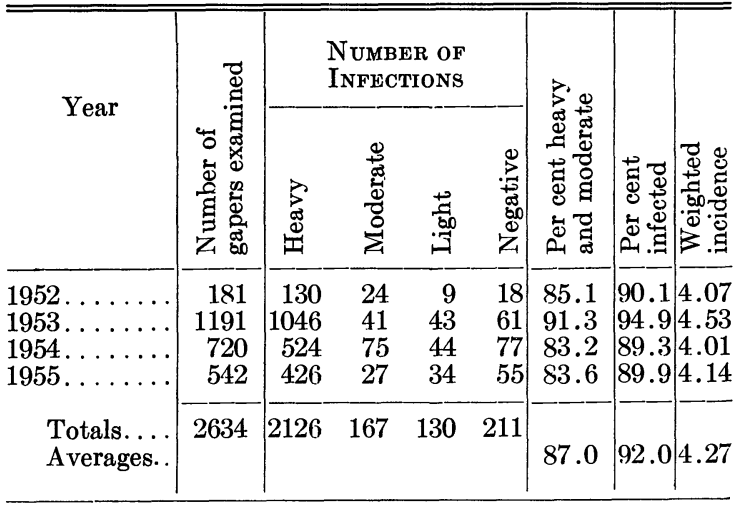

in previous years and persisted at a high rate in September and October, but the level of fungus infections in gapers was very similar to that of other years. It is concluded that the excessive losses in 1954 were caused primarily by the fungus.

\section{Incidence in Gapers from Outlying Trays and Natural Habitats}

The gapers collected from trays suspended in the Rappahannock River and Hampton Roads, although few in number, exhibited incidences and intensities of infections similar to gapers taken from the trays at Gloucester Point. Twenty-six of 37 gapers, from trays located at places other than the Laboratory pier, had serious infections and some of the remaining gapers were collected at times of the year when fungus infections were rare or absent.

Over one-half of the 36 gapers recovered from natural habitats had serious infections. It is assumed that some oysters on natural grounds died from causes other than the fungus; therefore, it was not expected that intensities and percentages of infections would equal those found in gapers from protected oysters in trays. Nevertheless, the data on gapers support the conclusion that the fungus is equally destructive to oysters in trays and on natural bottoms. The data on live oysters from natural grounds strongly confirm this conclusion. We believe, therefore, that deaths caused by the fungus, at the rates found in tray oysters, are in large part added to other lethal factors of natural bottoms.

\section{RECAPITULATion}

The studies of gapers from trays have shown that nearly $90 \%$ had serious infections of the fungus. The period of high death rates in the warm season coincides with high incidences of the fungus in live oysters and gapers. More intense infections in gapers than in live oysters indicate a pathogenic role for the fungus. Death rates varied from year to year but the percentage of deaths caused by the fungus remained high each year.

\section{DISTRIBUTION OF DERMOCYSTIDIUM MARINUM IN CHESAPEAKE BAY}

The known distribution of the fungus in Chesapeake Bay is derived from thioglycollate tests of live oysters collected from numerous localities. The samples, usually of 25 oysters or more, were tested as quickly as possible after removal from the water. To ensure that samples were representative for the area, only native oysters or those which had been growing in the locality at least two years were used. Except in seed areas, where the largest and oldest oysters available were selected, tests were made on market-sized oysters.

The five series of monthly tests revealed that high levels of infection prevailed in live oysters from September through November. It is believed that samples taken within this period indicated approximately the peak levels of infeetion for the year. Oyster populations near the fringes of the range of the fungus may not reach maximum levels of infection until November. In the fall, high salinities usually prevail, and presumably an abundant supply of infective material is provided by the disintegration of numerous gapers, therefore spores are probably carried farther up the estuaries in the fall than in summer.

The stations sampled for the fungus are grouped by major oyster-producing areas of the Bay. In the distribution studies alone 87 samples consisting of over 2000 oysters were tested for the fungus. Only a few samples were examined in 1952 and most of these were from the lower part of the Bay. In 1953 the survey was expanded to include the James River, the western shore of Chesapeake Bay, and the Seaside of Virginia and Maryland. In 1954 efforts were made to determine the limits of the range of the fungus in the Bay and its major tributaries. The range, as also the intensity and incidence of infections, probably will vary with climatological conditions from year to year. Therefore, the data from the 1954 samples (Fig. 3) present a general picture of the distribution and the relative intensity of the disease in major oystergrowing areas. In live oysters tested in September and October, weighted incidences of 1.0 and infections of $60 \%$ were considered high levels of infection; values of less than 0.5 and $30 \%$ indicated low intensity of the disease.

Tests of oysters in 1953 indicated that infections were rare in the James River seed area. Only two infections of Dermocystidium have been found in tests of hundreds of oysters from Wreck Shoal, an important ground in the middle of the seed area. A single infection was found in a sample of 50 old systers dredged from deep water along the edge of the channel one-half mile below Wreck Shoal. Sinilar samples taken along the channel in the lower part of the seed area contained very few infected oysters. Unfortunately no systematic check was made of the James River seed area in 1954, a 


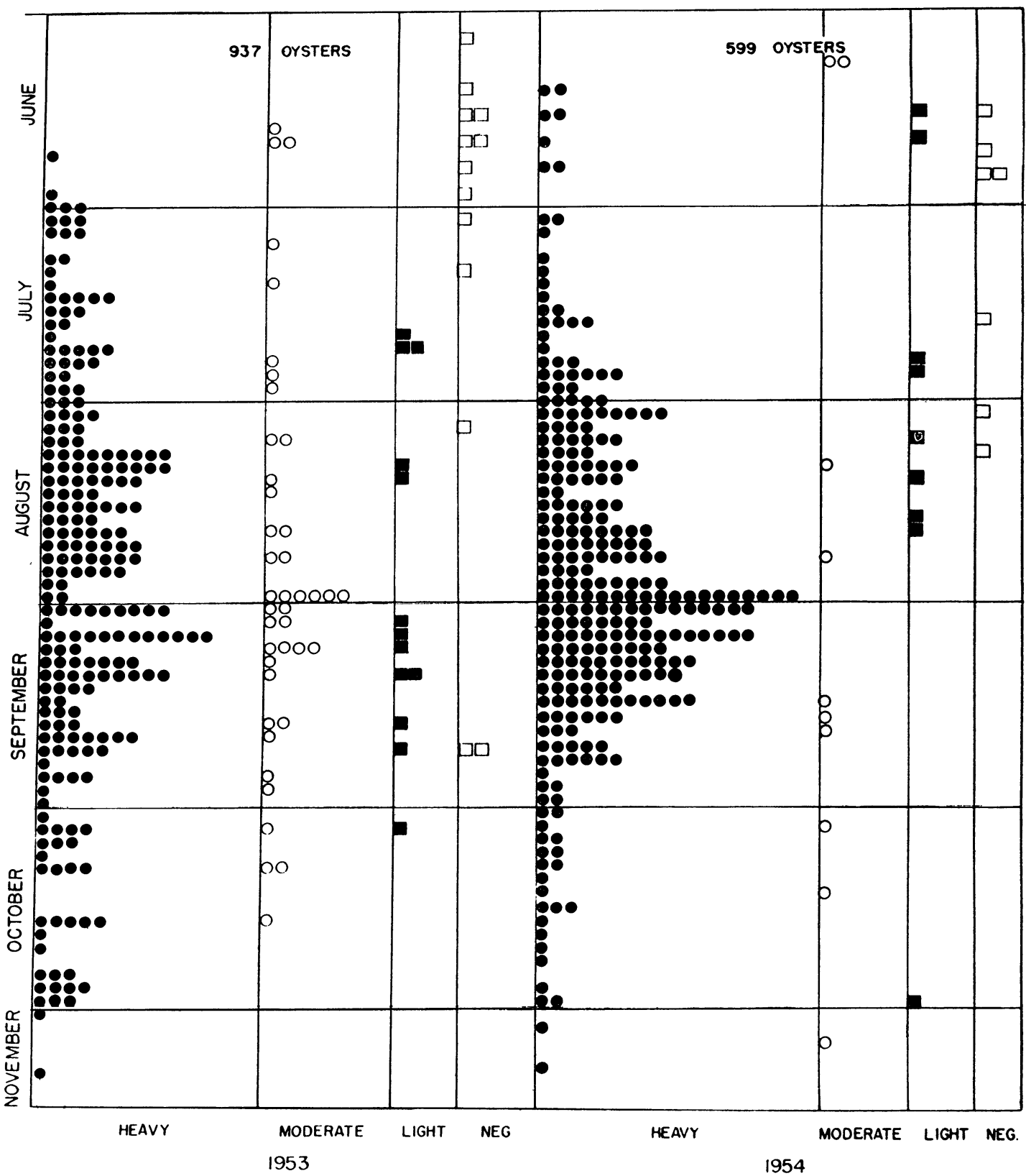

Frg. 2. The seasonal occurrence and intensity of fungus infections in gapers. Deaths are depicted chronologically and the incidences and intensities of fungus infections are indicated for Trays 1 to 3 and 6 to 10. Each circle or square represents one gaper. The number of oysters at the beginning of each warm season is shown at the top of the figure and the symbols for heavy, moderate and light infections are defined at the bottom of the figure. Gapers were grouped by 2-day intervals although they were collected daily. Further data on infections in gapers are given in Table 3.

year of greater fungus activity than 1953, but the pattern of very low incidence was repeated in 1955 . In Hampton Roads high levels of infection were found consistently during the warm seasons. The seasonal picture of the occurrence of the fungus in this area: is presented in Table 2.

The disease is intense in the lower "part of the York River, and its range seems to extend over the entire oyster-producing area in this river. Extensive data on the seasonal occurrence of the fungus at Gloucester Point indicate that the weighted incidence exceeds 1.0 and a large proportion of live oysters becomes infected each year (Table 2). Intensity of the disease is relatively low in the Rappahannock River although the fungus occurs throughout most of the oyster-producing area. It 


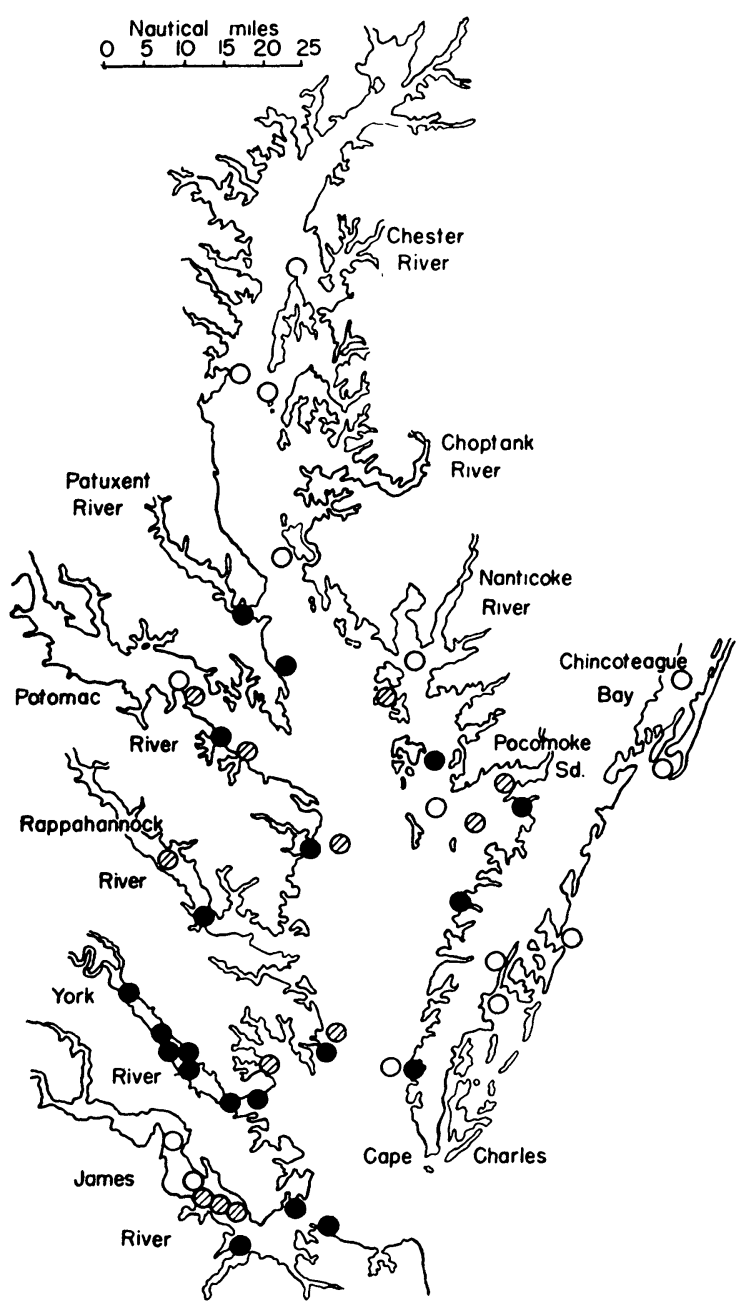

FIG. 3. The distribution of D. marinum in Chesapeake Bay. The closed circles indicate substantial infections (weighted incidence of 0.5 or greater), cross-hatched circles represent light infections, and open circles denote absence. Each symbol represents a station from which one or more samples were taken. The distribution in 1954 is depicted except in the James River seed area; not all stations and samples for other years are represented.

has been shown that incidence of infection and mortalities are comparatively low at the Hoghouse station in the Rappahannock. In the Potomac, the fungus appears only near the mouth of the river, and all the samples, except one from the Yeocomico River, had very low levels of infection. All of the Potomac River samples consisted of old native oysters from public grounds.

The western shore of Chesapeake Bay in Virginia showed substantial infections in the open Bay up to the Great Wicomico River, but a low level of infection at the mouth of the Potomac River. On the eastern shore of Chesapeake Bay in Virginia, the occurrence of infections is somewhat variable with occasional negative samples in areas where other samples have shown numerous infections. The fungus appeared to be searce in 1953 on grounds which had moderate numbers of infections in 1954, and it is possible that the disease has not yet extended into all suitable habitats along this shore. Plantings in the open Bay along the peninsula shore are infrequent and there are indications that the incidence of fungus on these grounds is low. Samples from Pocomoke Sound showed rather low levels of infection in 1954 but the weighted incidence was higher in 1955. In Maryland the fungus extended up the western shore of Chesapeake Bay from the Potomac River to the mouth of the Patuxent River. The distribution in Holland Straits and Tangier Sound is not clear, for some groups had infections and others did not.

The most baffling fact about the distribution of the fungus in the region is the almost complete absence of infections along the Seaside of Virginia and Maryland. Seed oysters are usually exported from the Seaside of Virginia but in Chineoteague Bay seed oysters are often imported from Chesapeake Bay. It is improbable that the fungus has not been afforded the opportunity to become established in Seaside waters, and high temperatures and salinities during the summer should provide a favorable environment.

Samples of oysters from South Carolina and Delaware Bay were also tested for Dermocystidium. Live oysters from South Carolina had a weighted incidence of 0.92 in November 1953. Only one infection was found in a sample of 50 oysters taken from "The Ledge" in Delaware Bay in December 1953, but Hugh J. Porter of the University of Delaware Marine Laboratories (personal communication) found numerous infections in Delaware Bay in 1954. Ray (1954) discusses the general distribution of the disease along the Atlantic and the Gulf coasts.

The range of the fungus in Chesapeake Bay in 1954 is shown in Fig. 3. With rare exceptions, all samples within this range showed infections and the fungus appears to be thoroughly distributed in the lower Bay. The disease occurs on most oyster grounds in Virginia and a few in Maryland. For convenience, the upper boundaries of the fungus range in each river and the Bay are associated with salinity levels regardless of the real limitin; $;$ factors. The boundary, which fluctuates with seasonal conditions, approximates the late summer isohaline of 15 parts per thousand (Pritchard 1952). 1954 was dry with high salinities and a prolonged hot season, and it is probable that the fungus reached its maximum penetration up the Bay in that year. It is possible also that the incidence and intensity of the disease rise and wane over the years irrespective of temperatures and salinities. There is a slight possibility that the fungus has been recently introduced in the Bay and is still spreading.

It was impossible to obtain sufficient gapers to 
determine the extent of fungus-caused mortalities over the full range of the disease. In areas of minimal salinities, infections probably occur too late and are too light to cause many deaths.

\section{FUNGUS INFECTIONS IN RELATION TO AGE AND SOURCE OF OYSTERS}

Ray (1954a) reported that in the Gulf of Mexico young oysters were less susceptible to $D$. marinum infection than old oysters; at an age of one year, only about one-third of a group of experimental oysters was found to be infected, whereas the frequency of infection was very high in older oysters. In Chesapeake Bay, Hewatt \& Andrews (1954b) found a low death rate in oysters under 2 yrs of age. After initial deaths of spat from other causes, few oysters were lost during their second summer (yearlings) and before the beginning of their third summer (2-yr-olds). The low summer death rates in oysters under 2 yrs of age suggested that in Chesapeake Bay also, young oysters were less susceptible to fungus infection.

The study of oysters of known age led to the discovery that the source of oysters also had a bearing on death rates and fungus infections. In 1951 and 1952, spat from the Seaside of the Eastern Shore, Virginia, and We Creek, South Carolina, were moved to trays at Gloucester Point to provide oysters of known age and history (Table 1). These spat had been caught on shells in the intertidal zone where most of the surviving set occurs in these localities. In this paper "Seaside" refers to the waters of the ocean-side of the Delmarva Peninsula (Cape Henlopen to Cape Henry). In August 1953 it was noted that yearlings from Seaside were dying at a rate very excessive for young oysters and that most of the gapers had heavy infections of the fungus. In contrast, 2-yr-old oysters obtained from South Carolina were dying at a much lower rate than expected, and most of the gapers were free of fungus infections. Both Seaside and South Carolina oysters had been grown in trays at Gloucester Point from spat size; therefore a difference in susceptibility to the fungus in oysters from the two sources was suggested.

\section{Data From Live Oysters}

After finding dissimilar mortalities among young oysters, and disparities in the fungus infections in gapers, the next logical step was to test live oysters from Chesapeake Bay, Seaside, and South Carolina for the fungus. Live yearling oysters, which as spat had been moved in the summer and fall of 1952 from their respective localities to Gloucester Point, were tested in September 1953. Infections were common in the yearlings from Seaside but rare in the other groups (Table 5, Trays 27, 15, and 33 for 1953).

To verify these observations, new collections of spat from the three areas were obtained in the fall
TABLE 5. Comparison of $D$. marinum infections in tray-grown live oysters of various ages and sources ${ }^{1}$.

\begin{tabular}{|c|c|c|c|c|c|c|c|c|}
\hline 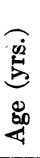 & Source & 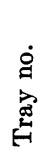 & 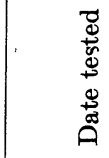 & & 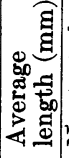 & $\mid \begin{array}{c}0 \\
\dot{0} \\
0 \\
0 \\
\vdots \\
\dot{2} \\
\dot{z}\end{array}$ & 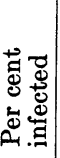 & 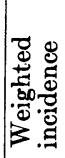 \\
\hline \multirow[t]{3}{*}{1} & South Carolina & 4 & 7 Sep & '52 & $68:$ & 25 & 20 & 0.20 \\
\hline & $\begin{array}{l}\text { South Carolina } \\
\text { Seaside } \\
\text { York River } \\
\text { Corrotoman R. }\end{array}$ & $\begin{array}{l}27 \\
15 \\
33 \\
26\end{array}$ & $\begin{array}{ll}4 & \text { Sep } \\
5 & \text { Sep } \\
4 & \text { Sep } \\
1 & \text { Dec } \\
\end{array}$ & $\begin{array}{l}' 53 \\
, 53 \\
, 53 \\
' 53 \\
\end{array}$ & $\begin{array}{r}74 \\
79 \\
77\end{array}$ & $\begin{array}{l}50 \\
25 \\
50 \\
25\end{array}$ & $\begin{array}{r}10 \\
64 \\
0 \\
20\end{array}$ & $\begin{array}{l}0.10 \\
0.88 \\
0.00 \\
0.20\end{array}$ \\
\hline & $\begin{array}{l}\text { South Carolina } \\
\text { Chincoteague } \\
\text { York River }\end{array}$ & $\begin{array}{l}38 \\
39 \\
40\end{array}$ & $\begin{aligned} 6 & \text { Sep } \\
8 & \text { Sep } \\
24 & \text { Sep }\end{aligned}$ & $\begin{array}{l}' 54 \\
' 54 \\
' 54\end{array}$ & $\begin{array}{l}\cdots \\
\cdots \\
\cdots\end{array}$ & $\begin{array}{l}25 \\
23 \\
25\end{array}$ & $\begin{array}{l}16 \\
52 \\
20\end{array}$ & $\begin{array}{l}0.16 \\
0.60 \\
0.52\end{array}$ \\
\hline \multirow[t]{3}{*}{2} & $\begin{array}{l}\text { James River } \\
\text { South Carolina }\end{array}$ & $\begin{array}{r}11 \\
4\end{array}$ & $\begin{aligned} 28 & \text { Aug } \\
7 & \text { Sep }\end{aligned}$ & $\begin{array}{l}' 53 \\
' 53\end{array}$ & $\begin{array}{r}81 \\
100\end{array}$ & $\begin{array}{l}37 \\
25\end{array} \mid$ & $\begin{array}{l}35 \\
20\end{array}$ & $\begin{array}{l}0.78 \\
0.20\end{array}$ \\
\hline & $\begin{array}{l}\text { York River } \\
\text { James River } \\
\text { Seaside }\end{array}$ & $\begin{array}{l}33 \\
37 \\
15\end{array}$ & $\begin{aligned} 5 & \text { Nov } \\
5 & \text { Nov } \\
27 & \text { Oct }\end{aligned}$ & $\begin{array}{l}' 54 \\
, 54 \\
' 54\end{array}$ & $\begin{array}{c}87 \\
81 \\
\ldots\end{array}$ & $\begin{array}{l}25 \\
25 \\
17\end{array} \mid$ & $\begin{array}{l}76 \\
76 \\
94\end{array}$ & $\begin{array}{l}1.56 \\
1.40 \\
1.88\end{array}$ \\
\hline & $\begin{array}{l}\text { South Carolina } \\
\text { Chincoteague } \\
\text { York River }\end{array}$ & $\begin{array}{l}38 \\
39 \\
40\end{array}$ & $\begin{array}{ll}25 & \text { Oct } \\
25 & \text { Oct } \\
25 & \text { Oct }\end{array}$ & $\begin{array}{l}' 55 \\
, 55 \\
\text { '55 }\end{array}$ & $\begin{array}{l}79 \\
76 \\
77\end{array}$ & $\left|\begin{array}{l}25 \\
25 \\
25\end{array}\right|$ & $\begin{array}{l}40 \\
68 \\
72\end{array}$ & $\mid \begin{array}{l}0.56 \\
1.00 \\
0.88\end{array}$ \\
\hline \multirow[t]{2}{*}{3} & $\begin{array}{l}\text { James River } \\
\text { South Carolina }\end{array}$ & $\begin{array}{r}11 \\
4\end{array}$ & $\begin{array}{ll}31 & \text { Aug } \\
31 & \text { Aug }\end{array}$ & $\begin{array}{l}' 54 \\
' 54\end{array}$ & 102 & $\left|\begin{array}{l}25 \\
25\end{array}\right|$ & $\begin{array}{l}96 \\
33\end{array}$ & $\begin{array}{l}1.76 \\
0.42\end{array}$ \\
\hline & $\begin{array}{l}\text { Corrotoman R. } \\
\text { York River } \\
\text { James River }\end{array}$ & $\begin{array}{l}26 \\
33 \\
37\end{array}$ & $\begin{array}{ll}17 & \text { Nov } \\
17 & \text { Nov } \\
17 & \text { Nov }\end{array}$ & $\begin{array}{l}' 55 \\
' 55 \\
' 55\end{array}$ & $\begin{array}{l}91 \\
96 \\
93\end{array}$ & $\begin{array}{l}25 \\
25 \\
25\end{array}$ & $\begin{array}{l}92 \\
80 \\
88\end{array}$ & $\begin{array}{l}1.32 \\
1.20 \\
1.36\end{array}$ \\
\hline \multirow[t]{2}{*}{4} & Seaside & 5 & 27 Oct & '54 & . & 12 & 100 & 1.83 \\
\hline & $\begin{array}{l}\text { South Carolina } \\
\text { James River }\end{array}$ & $\begin{array}{r}4 \\
11\end{array}$ & $\begin{array}{ll}10 & \text { Sep } \\
10 & \text { Sep }\end{array}$ & $\begin{array}{l}' 55 \\
' 55\end{array}$ & $\begin{array}{l}106 \\
100\end{array}$ & 25 & $\begin{array}{l}40 \\
96\end{array}$ & $\begin{array}{l}0.88 \\
1.84\end{array}$ \\
\hline
\end{tabular}

${ }^{1}$ All groups, except South Carolina, Seaside and Chincoteague Bay, are native Chesapeake Bay oysters.

of 1953 for comparison of infections in yearling oysters in the summer of 1954. Thus in 1954, oysters of several year-classes from the three sources were available for comparison of fungus infections and mortalities. The results are arranged in Tables 5 and 6 according to the age of oysters and the year tested, but the discussion is by sourceareas.

In native Chesapeake Bay oysters, live yearlings had only a few infections and weighted incidences were low (Table 5). In 2-yr-old oysters, infections were much more numerous and varied from 35 to $76 \%$ according to the year of observation. When three or more years of age, most oysters were infected regardless of the year, and weighted incidences exceeded 1.0.

Seaside and Chincoteague Bay oysters, at all ages, had a higher incidence and intensity of fungus infections than natives (Table 5). The contrast was most marked among yearling's and 2-yr-olds. Older oysters, both from Seaside and Chesapeake Bay, had relatively high incidence and intensities of infections and large numbers of heavily-infected gapers were removed. Thus in old oysters infections 
seemed to reach a point of saturation, and further progress of the disease produced more gapers but little change in the level of infection in survivors. A comparison of Seaside and native Chesapeake Bay oysters of $3 \mathrm{yrs}$ of age and older reveals no apparent differences in the percentages of infections and weighted incidences, although only one small sample was available from. Seaside.

Oysters of all ages from South Carolina had much lower levels of fungus infection than oysters from Chesapeake Bay and Seaside (Table 5). South Carolina oysters of three different year-classes, tested as yearlings (Trays 4, $27 \& 38$ ), showed very few infections. Infections in 2-yr-olds (Tray 4) remained low $(20 \%)$ while native and Seaside groups had substantial infections. In 3-yr-olds (Tray 4), infections increased to $33 \%$, but were still far below those in other source-groups of the same age. Even as 4-yr-olds (Tray 4), these oysters were only $40 \%$ infected whereas in native oysters of the same age and history the level of infection was $96 \%$.

In oysters from all three sources, fungus infections increased with age until an age of 3 or 4 yrs was attained. The level of infection at a given age, however, varied according to the source of oysters. The general level of fungus infections, as found in acclimated native oysters 3 or more years of age, increased each year from 1952 to 1954 and declined in 1955; therefore, the level of infections in oysters of the same age and source varies from year to year and these variations correspond to some extent with the fluctuations in mortalities (Tables $5 \& 6$ ). For example, 2-yr-old oysters from Chesapeake Bay had weighted incidences of 0.78 in 1953, 1.40 to 1.56 in 1954, and 0.88 in 1955 . Although 1954 was clearly a year of excessively high mortalities, the 2-yr-olds did not have a high annual loss-presumably because few infections were carried through the winter and consequently infections developed late. Nevertheless, the high weighted incidence in November 1954 indicates that the death rate was high at the end of the warm season. Three-yr-olds from Chesapeake Bay had weighted incidences of 1.76 in 1954 and 1.20 to 1.36 in 1955 (Table 5), and mortalities were correspondingly higher in 1954 than in 1955 (Table 6). However, it must be concluded that a weighted incidence from one or more tests, however reliable as an instantaneous measure of fungus level, is not a very good indicator of fungus-caused deaths for the season. In other words, in a given area, it is not possible to predict the fungus-caused mortalities for the season by measuring the level of fungus infections in live oysters. The two are related but mortalities from the fungus are influenced by the time of infections, temperatures and other factors. When numerous infections occur early in the warm season, considerable mortality can be expected be. fore low temperatures inhibit the fungus.

A more detailed analysis of infections in live yearlings in 1954 indicates that as the season progressed infections gained in intensity. Our notes show that most of the infections in July, August and September were very light. In the October tests, only 3 of 20 infections were designated as very light. Therefore, the late tests, in mid-September and October, indicate most clearly the relative susceptibility of yearling oysters. South Carolina oysters showed very few infections (1 in 25), York River oysters a moderate number ( 6 in 25$)$, and the Chincoteague group a high number (15 in 25). The differences are evident in both the percentage of infection and the weighted incidences. A higher proportion of late stages of infection was encountered in yearlings than in older oysters. In other words, the numbers of infections in the yearling populations remained quite low but a high proportion of these were serious infections.

\section{DATA FROM GAPERS}

The data from gapers show again that Seaside and Chincoteague oysters are more susceptible and South Carolina oysters more resistant to the fungus than native oysters (Table 6). This is deduced from the death rates rather than from the incidences and intensities of the fungus in gapers. All gapers of 2 yrs of age or older, except those from South Carolina oysters (Trays $4 \& 38$ ) had over $90 \%$ infection, and the average intensity of the infections was closer to heavy (5.0) than to moderate (3.0). Thus infections in gapers from Seaside and Chesapeake Bay were similar, but the rate of death in oysters from all three sources varied widely. It has been shown already that most deaths in trays were caused by the fungus; therefore, these variations in death rates of oysters from the three localities suggest differences in susceptibility.

Death rates increased with age and varied with the year in patterns similar to those described for infections. In Chesapeake Bay oysters, yearlings had summer mortalities (June to October inclusive) of less than $10 \%, 2$-yr-olds from 17 to $26 \%$, and oysters 3 or more years of age from 26 to $67 \%$. The death rate was low for yearlings, increased with age, and leveled off at an age of 3 or $4 \mathrm{yrs}$. These mortality figures are the minimum and maximum for each age group during a two- or three-year period. Each year had a characteristic level of oyster losses which accounts for the wide range of values. In a given year, oysters of the same age had similar mortalities. For example, in 1954, 3-yr-old oysters from Trays 11 and 12 had death rates of 57 and $51 \%$, respectively.

In Table 7, the conclusion that the year and the age affect the death rate has been examined by the use of chi-square tests (Snedecor 1946: 205-206, Table 9.11). Although 2-yr-olds showed little difference in death rates in 1953 and 1954, 3-yr-olds exhibited wide variations in 1954 and 1955. A comparison of different age groups in the same year suggests wide disparities between 2- and 3-yr-olds 
TABLE 6. Comparison of D. marinum infections in gapers from tray-grown oysters of various ages and sources.

\begin{tabular}{|c|c|c|c|c|c|c|c|}
\hline $\begin{array}{c}\text { Age } \\
\text { (yrs.) }\end{array}$ & Year & Source & 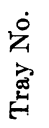 & 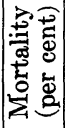 & 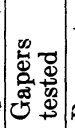 & 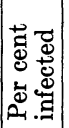 & 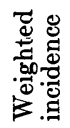 \\
\hline \multirow[t]{3}{*}{1} & 1952 & $\begin{array}{l}\text { South Carolina } \\
\text { James River } \\
\text { Corrotoman R. }\end{array}$ & $\begin{array}{r}4 \\
11 \\
12\end{array}$ & $\begin{array}{l}7 \\
4 \\
3\end{array}$ & $\begin{array}{l}4 \\
0 \\
0\end{array}$ & $\begin{array}{c}25 \\
\cdots \\
\cdots\end{array}$ & $\begin{array}{l}0.25 \\
\ldots \\
\cdots\end{array}$ \\
\hline & 1953 & $\begin{array}{l}\text { Seaside } \\
\text { RappahannockR. } \\
\text { Corrotoman R. }\end{array}$ & $\begin{array}{l}15 \\
25 \\
26\end{array}$ & $\begin{array}{r}30 \\
10 \\
4\end{array}$ & \begin{tabular}{r|}
31 \\
0 \\
0
\end{tabular} & $\begin{array}{c}87 \\
\cdots \\
\cdots\end{array}$ & $\begin{array}{l}3.19 \\
\ldots \\
\ldots\end{array}$ \\
\hline & 1954 & $\begin{array}{l}\text { South Carolina } \\
\text { Chincoteague } \\
\text { York River }\end{array}$ & $\begin{array}{l}38 \\
39 \\
40\end{array}$ & $\begin{array}{l}26 \\
16 \\
\cdots\end{array}$ & $\begin{array}{r}4 \\
16 \\
1\end{array}$ & $\begin{array}{r}25 \\
75 \\
100\end{array}$ & $\begin{array}{l}1.25 \\
3.12 \\
5.00\end{array}$ \\
\hline \multirow[t]{3}{*}{2} & 1953 & $\begin{array}{l}\text { South Carolina } \\
\text { James River } \\
\text { Corrotoman R. }\end{array}$ & $\begin{array}{r}4 \\
11 \\
12\end{array}$ & $\begin{array}{l}10 \\
24 \\
17\end{array}$ & $\begin{array}{l}27 \\
79 \\
33\end{array}$ & \begin{tabular}{|l|}
52 \\
91 \\
91
\end{tabular} & $\begin{array}{l}1.55 \\
4.20 \\
4.12\end{array}$ \\
\hline & 1954 & $\begin{array}{l}\text { Seaside } \\
\text { RappahannockR. } \\
\text { Corrotoman R. } \\
\text { York River } \\
\text { James River }\end{array}$ & $\begin{array}{l}15 \\
25 \\
26 \\
33 \\
37\end{array}$ & $\begin{array}{l}74 \\
54 \\
24 \\
18 \\
26\end{array}$ & $\begin{array}{r}41 \\
59 \\
157 \\
23 \\
82\end{array}$ & $\begin{array}{r}95 \\
100 \\
94 \\
91 \\
98 \\
\end{array}$ & $\begin{array}{l}4.56 \\
4.93 \\
4.48 \\
4.13 \\
4.46\end{array}$ \\
\hline & 1955 & $\begin{array}{l}\text { South Carolina } \\
\text { Chincoteague } \\
\text { York River }\end{array}$ & $\begin{array}{l}38 \\
39 \\
40\end{array}$ & $\begin{array}{l}12 \\
47 \\
24\end{array}$ & $\begin{array}{l}24 \\
97 \\
60\end{array}$ & $\begin{array}{l}62 \\
96 \\
85\end{array}$ & $\begin{array}{l}2.12 \\
4.78 \\
3.98\end{array}$ \\
\hline \multirow[t]{3}{*}{3} & 1953 & Seaside & 5 & 46 & 43 & 93 & 4.19 \\
\hline & 1954 & $\begin{array}{l}\text { South Carolina } \\
\text { James River } \\
\text { Corrotoman R. }\end{array}$ & $\begin{array}{r}4 \\
11 \\
12\end{array}$ & $\begin{array}{l}26 \\
57 \\
51\end{array}$ & $\begin{array}{r}36 \\
1.27 \\
82\end{array}$ & \begin{tabular}{|l|}
97 \\
98 \\
98
\end{tabular} & $\begin{array}{l}4.58 \\
4.73 \\
4.66\end{array}$ \\
\hline & 1955 & $\begin{array}{l}\text { RappahannockR. } \\
\text { Corrotoman R. } \\
\text { York River } \\
\text { James River }\end{array}$ & $\begin{array}{l}25 \\
26 \\
33 \\
37\end{array}$ & $\begin{array}{l}35 \\
33 \\
28 \\
35\end{array}$ & $\begin{array}{r}19 \\
153 \\
30 \\
59\end{array}$ & $\begin{array}{l}95 \\
96 \\
97 \\
98\end{array}$ & $\begin{array}{l}4.74 \\
4.77 \\
4.57 \\
4.58\end{array}$ \\
\hline \multirow[t]{2}{*}{4} & 1954 & Seaside & 5 & 71 & 32 & 100 & 4.94 \\
\hline & 1955 & $\begin{array}{l}\text { South Carolina } \\
\text { James River } \\
\text { Corrotoman R. }\end{array}$ & $\begin{array}{r}4 \\
11 \\
12\end{array}$ & $\begin{array}{l}22 \\
27 \\
30\end{array}$ & $\begin{array}{l}26 \\
23 \\
24\end{array}$ & \begin{tabular}{|l|}
62 \\
83 \\
96 \\
\end{tabular} & $\begin{array}{l}2.69 \\
4.22 \\
4.38\end{array}$ \\
\hline
\end{tabular}

but little indication of differences in the death rates of 3- and 4-yr-olds. Each age group, in a particular year, exhibits fairly consistent death rates, although occasional aberrant results are obtained (Tray 25 in 1954). Yearling oysters were not included in the table for it is obvious that mortality was much lower in these groups than in older oysters. Comparisons of oysters from Chesapeake Bay, South Carolina, and Seaside could be made but in general the differences in death rates are evident (Table 6). For the most part, the numbers of oysters used in these experiments seem to provide adequate estimates of the death rate.

Seaside oysters had summer death rates from 16 to $30 \%$ as yearlings, and a weighted incidence higher than 3.0 indicates that most of the gapers were well-infected with the fungus. In 2-yr-olds mortality rates were 37 to $74 \%$ and in older oysters 46 to
TABLE 7. Summary of statistical tests on mortality rates of Chesapeake Bay oysters for various years and ages.

\begin{tabular}{|c|c|c|c|c|c|c|}
\hline Age and year & Tray numbers & 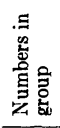 & 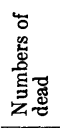 & 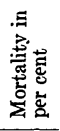 & $\ddot{x}$ & D \\
\hline $\begin{array}{l}\text { Two years old } \\
1953 \\
1954\end{array}$ & $\left|\begin{array}{r}11 \& 12 \\
25,26,33 \& 37\end{array}\right|$ & $\begin{array}{r}622 \\
1318\end{array}$ & $\begin{array}{l}13 \cdot 4 \\
353\end{array}$ & $\begin{array}{l}21.5 \\
26.8\end{array}$ & 6.22 & $\begin{array}{l}<0.02 \\
\text { (1 d.f.) }\end{array}$ \\
\hline $\begin{array}{c}\text { Three years old } \\
1954 \\
1955\end{array}$ & $\left|\begin{array}{r}11 \& 12 \\
25,26,33 \& 37\end{array}\right|$ & $\begin{array}{l}430 \\
846\end{array}$ & $\begin{array}{l}235 \\
279\end{array}$ & $\begin{array}{l}54.7 \\
33.0\end{array}$ & 0.89 & $\begin{array}{l}<0.01 \\
(1 \text { d.f. })\end{array}$ \\
\hline $\begin{array}{l}1954 \text { samples } \\
\text { Two years old } \\
\text { Three years old }\end{array}$ & $\left|\begin{array}{r}25,26,33 \& 37 \\
11 \& 12\end{array}\right|$ & $\begin{array}{r}1318 \\
430\end{array}$ & $\begin{array}{l}353 \\
235\end{array}$ & $\begin{array}{l}26.8 \\
54.7\end{array}$ & 114.66 & $\begin{array}{l}<0.01 \\
(1 \text { d.f. })\end{array}$ \\
\hline $\begin{array}{l}1955 \text { samples } \\
\text { Three years old } \\
\text { Four years old }\end{array}$ & $\left|\begin{array}{r}25,26,33 \& 37 \\
11 \& 12\end{array}\right|$ & $\begin{array}{l}846 \\
179\end{array}$ & $\begin{array}{r}279 \\
50\end{array}$ & $\begin{array}{l}33.0 \\
27.9\end{array}$ & 1.95 & $\begin{array}{l}<0.20 \\
(1 \text { d.f. })\end{array}$ \\
\hline Two years old, 1954 & $\begin{array}{l}25 \\
26 \\
\\
33 \\
37\end{array}$ & $\begin{array}{l}134 \\
689 \\
\\
165 \\
330\end{array}$ & $\begin{array}{r}72 \\
165 \\
\\
30 \\
86\end{array}$ & $\begin{array}{l}53.7 \\
23.9 \\
\\
18.2 \\
26.1\end{array}$ & 56.63 & $\begin{array}{l}<0.01 \\
(3 \text { d.f. })\end{array}$ \\
\hline Three years old, 1955 & $\begin{array}{l}25 \\
26 \\
\\
33 \\
37\end{array}$ & $\begin{array}{r}57 \\
491 \\
\\
107 \\
191\end{array}$ & $\begin{array}{r}20 \\
162 \\
\\
30 \\
67\end{array}$ & $\begin{array}{l}35.1 \\
33.0 \\
\\
28.0 \\
35.1\end{array}$ & 1.48 & $\begin{array}{l}>0.20 \\
(3 \text { d.f. })\end{array}$ \\
\hline Two years old, 1953 & $\begin{array}{l}11 \\
12\end{array}$ & $\begin{array}{l}404 \\
218\end{array}$ & $\begin{array}{l}99 \\
37\end{array}$ & $\begin{array}{l}24.5 \\
17.0\end{array}$ & 0.47 & $\begin{array}{l}<0.05 \\
(1 \text { d.f. })\end{array}$ \\
\hline Three years old, 1954 & $\begin{array}{l}11 \\
12\end{array}$ & $\begin{array}{l}259 \\
171\end{array}$ & $\begin{array}{r}147 \\
87\end{array}$ & $\begin{array}{l}56.8 \\
50.9\end{array}$ & 1.97 & $\begin{array}{l}<0.20 \\
\text { (1 d.f.) }\end{array}$ \\
\hline Four years old, 1955 & $\begin{array}{l}11 \\
12\end{array}$ & $\begin{array}{l}99 \\
80\end{array}$ & $\begin{array}{l}26 \\
24\end{array}$ & $\begin{array}{l}26.3 \\
30.0\end{array}$ & 0.31 & $\begin{array}{l}<0.60 \\
\text { (1 d.f.) }\end{array}$ \\
\hline
\end{tabular}

71\%. In South Carolina oysters, mortalities, like fungus infections, were unusually low. Except for one group of yearlings (Tray 38 in 1954), death rates were considerably lower in South Carolina oysters than in native oysters-until an age of 4 years was attained. Two-yr-olds had death rates of 10 to $12 \%, 3$-yr-olds $26 \%$, and 4-yr-olds $22 \%$. The weighted incidence was conspicuously lower in South Carolina gapers of all ages in all years than in gapers from other sources. The differences in death rates and fungus infections can be seen best by direct comparison in Table 6 .

\section{Recapitulation}

The studies on age and source of oysters reveal that the intensity of the fungus increases with age until oysters are 3 years old. South Carolina oysters are more resistant and Seaside of Eastern Shore 
oysters more susceptible to the fungus than native Chesapeake Bay oysters. In comparing susceptibility of oysters, incidences and intensities of infections are useful but death rates are more indicative in older oysters.

\section{EXPERIMENTAL INFECTION OF OYSTERS}

\section{INFECTION OF OLD OYSTERS}

In the summer of 1954 , to confirm the work of Mackin and Ray (Ray 1954b, c), experiments were conducted to induce infections in oysters. Fungusfree oysters, from: Deep Water Shoal in the James River, were separated into four groups (C1 to C4) of 20 each, and two holes were drilled through the shell into the mantle cavity of each oyster. All groups except the control (C2) were inoculated through the holes with 1 ce of macerated tissues of heavily-infected gapers. The number of spores per ec of this material was not known, but the count was undoubtedly high. The controls were injected with a similar preparation of macerated live uninfected oysters from Deep Water Shoal. After injection the oysters were held out of water overnight, then all groups were placed in aquaria of standing water, except $\mathrm{C} 4$, which was placed in a tray suspended in the York River from the Laboratory pier. The water in the aquaria was maintained at approximately $28^{\circ} \mathrm{C}$ and aerated.

Fig. 4 depicts the occurrence of gapers, the numbers of survivors, and the fungus infections in each group. Five oysters died in the first day or two and only one of these was infected. No further deaths occurred in the experimental groups until 22 days after infection. Deaths occurred rapidly thereafter until the experiment was terminated 37 days after experimental infection. Excepting the initial deaths, all but one of the gapers and survivors from the experimentally-infected group were infected. Nn infections were found in the control group although once a week the water in the aquaria was changed using unfiltered river water.

It appears that nearly all oysters became infected from 1 ec injections whether retained in aquaria or held in open waters. The first gapers occurred almost as soon in open waters as in heated aquaria, but, as groups, oysters developed infections earlier and died sooner in the aquaria. Our experiments seem to confirm those of Ray and Mackin even in small details.

In later experiments we confirmed Ray's (1954b) finding that infections could be induced by feeding suspensions of spores prepared in a Waring blendor or by squeezing the juices of minced gapers through cheese eloth. Infections developed more slowly by this method and intensities were not as uniform as those obtained by injection.

\section{INFECTION OF Young OYSTERS}

Physiological immunity to a disease is usually acquired with age; therefore, the low incidence of

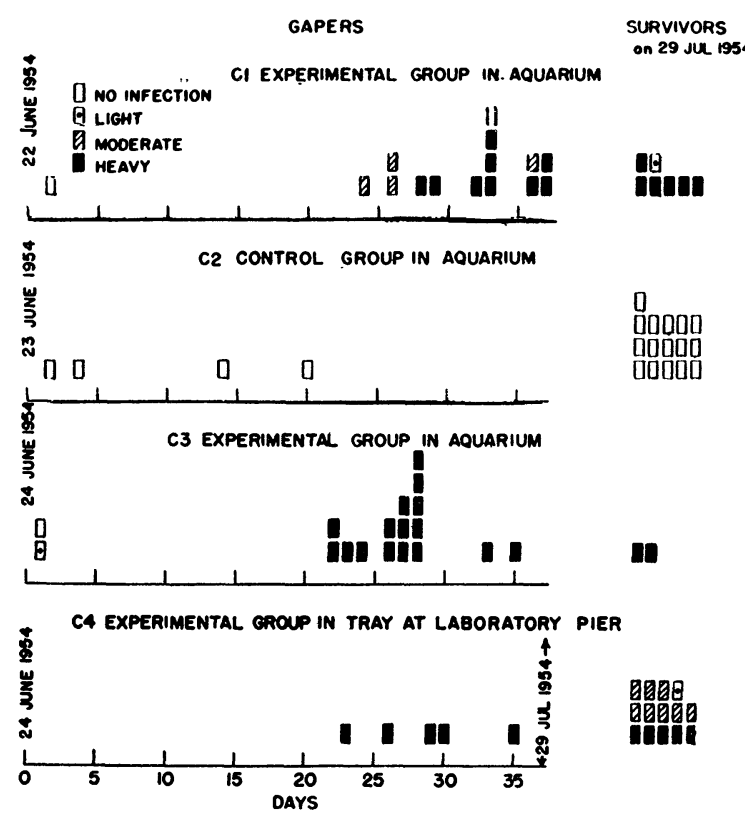

Fig.4. Experimental infection of oysters from Deep Water Shoal by injection of fungus-infected tissues into the mantle cavity. The control group received minced tissues from uninfected oysters. Each rectangle represents one oyster, and in gapers the position indicates the time of death expressed as the number of days after injection. The experiment was ended on July 29, 1954, and all survivors tested for the fungus.

the fungus in young oysters was puzzling. While only a few yearlings died, a high proportion of these had serious infections. This suggested that young oysters, though susceptible to the disease, failed to obtain infective doses of the fungus for mechanical reasons, perhaps because they pump relatively small amounts of water. Subjecting young oysters to concentrations of fungus spores was a logical test of this supposition.

In the summer of 1953, spat from Chincoteague Bay and South Carolina were transplanted to the Virginia Fisheries Laboratory. Chesapeake Bay native oysters were caught on shells at Gloucester Point. A year later these three groups of yearling oysters were exposed to the fungus in aquaria. Fifty yearling oysters from each source, and a control group of 252 - and 3-yr-old oysters from low salinity waters of the James River, were placed in aquaria. The inoculum, consisting of minced gapers with heavy infections, was fed to all oysters on July 22, 1954. The control group was fed the inoculum to insure that experimental infection was successful. One control and one experimental oyster, each with a light infection, died in July. The first heavily-infected gaper occurred on August 9. Two heavily-infected gapers were removed on August 18, and oysters died nearly every day thereafter until September 23, when nearly all were dead. 
All but two of the gapers had heavy infections and none was found to be free of infection.

Since young oysters were easily infected under experimental conditions, it appears that they fal to get infective doses of spores in natural waters. If a certain minimal quantity of spores must be acquired before infections develop, the density of spores in the water and the amount of water pumped would determine their rate of accumulation in the oyster tissues. A third factor may be the rate of expulsion of spores by the oyster. The amount of water pumped by an oyster is proportional to its size, therefore, yearling oysters would collect fewer spores and have fewer infections than larger and older oysters. Since oysters grow more quickly in southern waters, in yearlings the incidence of the fungus may be expected to be higher in Barataria Bay (Ray 1954a) than in Chesapeake Bay. In southern waters infective spores may also occur in greater densities.

\section{Cross-Infection Experiments with OTher Bivalves}

In the fall of 1953, we discovered that 13 of 16 bivalve species collected from the area of Gloucester Point were infected with a Dermocystidium-like parasite (Andrews 1956). In thioglycollate culture these parasites enlarged and stained with iodine in the same manner as the fungus parasite of oysters. Infections in these other bivalves were usually systemic but the fungus cells were more clustered and appeared to be enclosed in cýsts. In several species of bivalves, all specimens examined were infected, but the intensity was seldom rated above light.

Since some of the bivalve species seemed to carry their Dermocystidium-like parasites through the winter in a stage which responded to thioglycollate culture, it was important to determine if the same species of fungus was present in oysters and other bivalves and whether these other mollusks might provide an overwintering reservoir for the organisms producing disease in oysters. Cross-infection experiments therefore were attempted, using Venus mercenaria Linné and Macoma balthica Linné. At tempts to increase the intensity of infections in these bivalves by holding them in heated aquaria were unsuccessful. Venus lived well in the aquaria but Macoma, Tagelus plebius Solander and other active burrowing species did not survive long.

In June 1954, 42 clams (Venus) were injected through drilled holes with 1 ec of inoculum from infected oyster gapers. After one month not one infection had been found in gapers or survivors. Tissues remote from the site of injury caused by drilling and inoculation were selected to avoid the local infections reported by Ray (1954e). An attempt was made to infect oysters by feeding inoculum prepared from infected Macoma but results were again negative. Other species of bivalves were injected with inoculum from oyster gapers but failed to live long enough for infections to develop.

\section{THE EFFECTS OF TEMPERATURE ON FUNGUS INFECTIONS}

\section{Seasonal and Geographical Effects}

Temperature is obviously the ehief factor regulating epidemies of the disease, for the fungus requires warm water to multiply and to kill oysters. This is illustrated most vividly by the extremely high mortalities caused by the fungus in the Gulf of Mexico and the apparent absence of the disease in New England. In Barataria Bay, Louisiana, deaths from the fungus occur almost throughout the year (Mackin 1953). The intensity of infection in live oysters decreases during the winter months, but the incidence remains high. In Chesapeake Bay, mortalities are essentially restricted to a five-month period of warm weather, and infections almost completely disappear in the winter. In Delaware Bay, conspicuous mortalities of oysters of unknown cause were found during the warm fall of 1954 . Oyster tissues cultured by Hugh J. Porter contained substantial infections of the fungus (personal communication). The fungus has not been found in Long Island Sound although infected oysters from southern waters have been introduced numerous times. It appears that in these northern waters winter temperatures are too low and the period of high temperatures too short for the fungus to flourish.

In Chesapeake Bay, infections of live oysters are infrequent until June when water temperatures have reached approximately $25^{\circ} \mathrm{C}$. This may not reflect a temperature requirement but rather a scarcity of infective spores since few gapers occur between December and June. Some oysters in infested areas carry infections through the winter, however, and presumably in these oysters an increase in intensity does not require additional infective material from the water.

In August and September 1953 and 1954, it was believed that the fungus was responding sharply to a temperature change of a few degrees in the range of $28^{\circ}$ to $30^{\circ} \mathrm{C}$, for greater numbers of gapers seemed to be retrieved following intensely hot periods. In the fall of 1954, the persistence of high temperatures until the middle of October appeared to be the cause of excessive losses of oysters. On the contrary, July and August 1955, though exceptionally hot months, produced low mortalities. Perhaps short periods of very hot weather, especially late in the season after infections are well developed, are more important than average monthly temperatures. If summer temperatures persisted longer in Chesapeake Bay, as they do in the Gulf of Mexico (Owen 1953), mortalities almost certainly would rise sharply.

The incidence and intensity of infection do not decline until December, when temperatures have usually dropped below $10^{\circ} \mathrm{C}$. The temperatures at which the fungus becomes active in the early summer (about $25^{\circ} \mathrm{C}$ ), and those prevailing when infections begin to wane, show a wide discrepancy. The fungus, once established in oysters, will evidently 
persist at moderately low temperatures, but it requires higher temperatures to multiply and to increase the intensity of infections (Mackin 1953). The scarcity of spores in spring and early summer, and their abundance in fall, are presumably important factors affecting the seasonal changes in fungus infections. Since oysters in Chesapeake Bay become inactive in December, it would appear that adverse physical conditions probably eliminate or reduce the abundance of spores. Yet, occasional heavilyinfected oysters are encountered in February and March, suggesting that the fungus will tolerate low temperatures. Furthermore, we have found that some spores in gapers will tolerate freezing several times and still respond to thioglycollate culture.

\section{Overwintering of the Fungus in Live Oysters}

Ray (1954c) showed by "proximity" studies that the fungus was transmitted from one oyster to another in closed aquaria and that many Louisiana oysters, collected in winter and placed in warm water aquaria, would develop the disease in one or two months. Since our monthly thioglycollate tests of live oysters rarely disclosed infections in late winter and spring, we turned to Ray's method to detect overwintering infections. Five small groups of oysters were placed in closed aquaria in the spring of 1954 and held at temperatures which varied from $23^{\circ}$ to $28^{\circ} \mathrm{C}$ (Fig. 5). The water in the aquaria
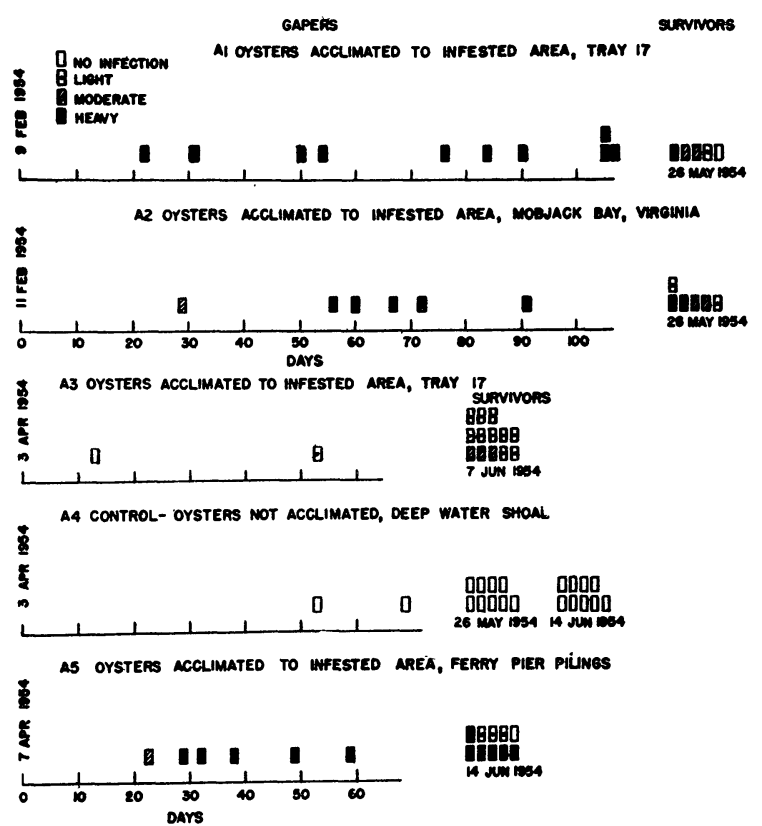

FIG. 5. Overwintering of $D$. marinum in oysters. The timing, incidence, and intensity of infections in oysters moved in winter and spring from the cold waters of natural habitats to the warm waters $\left(23^{\circ}\right.$ to $\left.28^{\circ} \mathrm{C}\right)$ of aquaria. Each rectangle represents an oyster, and in gapers the position indicates the time of death expressed as the number of days after being placed in aquaria. Survivors were tested at the end of the experiments on the dates written below the symbols. was replaced several times with unfiltered river water. The oysters in experiments A-1 and A-3 were taken from Tray 17, for which there was a monthly record of the level of infections by the thioglycollate culture test (Table 2). The oysters in A-2 and A-5 were collected from infested areas and the control group, A-4, was obtained from a disease-free area of the James River. In 68 days not a single infection developed in gapers or survivors in the control group. This confirms the usefulness of Ray's method and substantiates his statement that the use of open river waters in limited quantities does not produce infections. When the first gaper occurred in the control group, half of the survivors were opened and tested for the fungus before infections could be acquired from the gaper, which might have been infected.

In acclimated and experimentally-infected oysters, the first heavily-infected gapers appeared within one month, but it is impossible to determine from these experiments how many oysters bore overwintering infections, because proximity infections may have occurred. The time-distribution of deaths suggests that initially only two oysters in A-1 and a single oyster in A-2 had infections. It has been shown in the section on experimental infections that most oysters injected with inoculum and held at $28^{\circ}$ to $30^{\circ} \mathrm{C}$ gaped in about 30 days.

The monthly tests of live oysters revealed that the lowest level of infections usually occurred in April and May. Experiment A-3, begun in April, suggests that infections may be acquired in closed aquaria from the fecal discharges of infected oysters. In 64 days, of the two oysters that died, one was negative and the other had a light infection. Since both of these gapers were removed as quickly as they occurred, there was little chance for their disintegration, yet all 13 of the survivors were infected. The alternative conclusion is that all but one of the $\mathbf{1 5}$ oysters was carrying overwintering infections. We know that some infections, not detected by the thioglycollate method, are carried through the winter, and thus the determination of the incidence of the fungus in winter and spring requires the isolation of each oyster.

\section{ExPERIMENTAL INFECTION OF OYSTERS at Various Temperatures}

In 1954 an attempt was made to infect oysters at low temperatures. On July 1, 60 oysters were collected from Deep Water Shoal, a disease-free area of the James River. Two small holes were drilled in the shell of each oyster to permit introduction of infective material into the mantle cavity (Ray 1954e). Half of the oysters were placed in a standing-water aquarium and the temperature slowly lowered to $5^{\circ} \mathrm{C}$. The remainder were kept in an aquarium maintained at approximately $28^{\circ} \mathrm{C}$. After three days a mince prepared from heavily-infected gapers was injected into the mantle cavity of each oyster, and all were returned to their respective 
aquaria without temperature changes. The oysters in water at $5^{\circ} \mathrm{C}$ appeared to be inactive; therefore, after a period of 10 days, the temperature was raised to $15^{\circ} \mathrm{C}$. At intervals during the six-week period of the experiment, a few oysters were removed and tested for Dermocystidium. None of the oysters kept at the low temperatures was found to be infected, but after the first two weeks of the experiment all of the oysters kept at room temperature had developed fungus infections ranging from light to heavy.

In another experiment (Hewatt \& Andrews 1956) oysters were experimentally infected with the fungus and held at $28^{\circ} \mathrm{C}$ for one week to permit infections to develop. The oysters were then transferred to a standing-water aquarium and the water temperature was gradually reduced to $15^{\circ} \mathrm{C}$. A control group of oysters was held at $28^{\circ} \mathrm{C}$. All but one of the control oysters had died by the end of the six-week period, and in this group almost all of the gapers had heavy infections. The development of infections in the oysters held at $15^{\circ} \mathrm{C}$ was definitely arrested. Of the original 100 experimental oysters only 10 died, and fungus infections were light or absent. These experiments suggest that Dermocystidium does not infect oysters at low temperatures and that development of established infections is retarded at temperatures below $15^{\circ} \mathrm{C}$.

\section{RECAPITULATION}

The fungus multiplies and spreads during the warm season but is gradually eliminated in winter and spring; relatively few oysters carry infections through the winter. These low-grade infections apparently provide a nucleus of infective-material for the epidemic of disease the next summer. Infections persisted in oysters held at $15^{\circ} \mathrm{C}$ but development was retarded and new infections did not occur at this temperature.

\section{THE RELATIONSHIP OF SALINITY AND FUNGUS INFECTIONS}

\section{Range of the Fungus and Isohalines}

In Chesapeake Bay, D. marinum infections are usually absent in oysters from waters with a mean summer salinity of approximately $15 \%$ or less, thus large areas of productive oyster grounds up the Bay and rivers are essentially free of the disease. Mackin (1956) has reviewed the relation of $D$. marinum to salinity and concluded that the fungus has a salinity tolerance almost as great as that of oysters. In Redfish Bay, Louisiana, he found oysters growing satisfactorily at a mean salinity of 7 to $8 \%$ and low levels of fungus infection at 8 to $9 \%$. In contrast to the condition found in Chesapeake Bay, fungus-free areas suitable for oyster production are very limited in Louisiana. Mackin believes that low salinity per se may have a retarding effect on the development of the disease but that it does not present an effective physiological barrier to the fungus. He suggests that dilution by fresh water inflow tends to reduce the concentration of water-borne infective cells. In low-salinity areas, therefore, infections may not occur because infective cells are absent or scarce. The low incidence of the fungus in Chesapeake Bay waters with salinities less than 15 and its presence in Redfish Bay in salinities of 7 to $8 \%$ oo may reflect the relative flushing rates of the two areas.

TABLE 8. Salinities in the rivers of lower Chesapeake $\mathrm{Bay}^{\mathrm{I}}$.

\begin{tabular}{|c|c|c|c|c|}
\hline \multirow[t]{2}{*}{ Stations $^{2}$} & \multirow{2}{*}{$\begin{array}{l}\text { Num- } \\
\text { ber of } \\
\text { samples }\end{array}$} & \multicolumn{3}{|c|}{$\begin{array}{l}\text { Salinity in Parts } \\
\text { Per Thousand }\end{array}$} \\
\hline & & Mean & $\begin{array}{l}\text { Mini- } \\
\text { mum }\end{array}$ & $\begin{array}{l}\text { Maxi- } \\
\text { mum }\end{array}$ \\
\hline \multicolumn{5}{|l|}{$\begin{array}{l}\text { James River (Records of } \\
\text { July to September only) }\end{array}$} \\
\hline & 115 & 17 & 9 & 22 \\
\hline Wreck Shoal, J $17 \ldots \ldots \ldots$ & 359 & 14 & 4 & 20 \\
\hline & 108 & 7 & 1 & 13 \\
\hline \multicolumn{5}{|l|}{$\begin{array}{l}\text { York River (All available } \\
\text { records) }\end{array}$} \\
\hline Gloucester Point, Y $6 \ldots$ & 1105 & 20 & 11 & 25 \\
\hline Bell's Rock, Y 25 (surface). & 42 & 10 & 2 & 21 \\
\hline$" \quad " \quad "(25$ feet $) \ldots$ & 33 & 14 & 6 & 22 \\
\hline \multicolumn{5}{|l|}{$\begin{array}{l}\text { Rappahannock River (All } \\
\text { available records) }\end{array}$} \\
\hline Broad Creek, R 0. & 71 & 16 & 8 & 22 \\
\hline Hoghouse Rock, R 15... & 50 & 15 & 9 & 21 \\
\hline Morattico, R 25...... & 26 & 12 & 7 & 20 \\
\hline Ross Rock, R 35. . . . . & 10 & 9 & 1 & 16 \\
\hline $\begin{array}{l}\text { Potomac River (All available } \\
\text { records) }\end{array}$ & & & & \\
\hline Mouth of river, $\mathrm{P} 0 \ldots \ldots \ldots$ & 5 & 14 & 11 & 17 \\
\hline
\end{tabular}

${ }^{1}$ Scattered records mostly from the Virginia Fisheries Laboratory, but some from Chesapeakt Bay Institute.

2The letters and numbers are station designations indicating distance in nautical miles from the mouths of rivers.

In Table 8 the means and extremes of salinity have been determined for comparison with the distribution of the fungus. Several salinity stations near the borders of the range of the fungus have been included along with stations within and outside the range. Since the fungus is most active in late summer and fall when salinities are usually highest for the vear, records for this period are perhaps the most significant. Because records were few, adequate data for summer periods were available only for the James River and Gloucester Point, and the salinities for the remaining stations include all records taken during the year.

The fungus is rare at the James River bridge where late-summer salinities average $17 \%$. The low incidence of the fungus at such a high salinity probably reflects the vigorous flushing action of the James River, which has a greater fresh water flow than the York and Rappahannock Rivers. The fungus is common at Nansemond Ridge, only a few miles below the bridge, where salinities are about $19 \%$. In contrast, at Bell's Rock in the York, 
and at the mouth of the Potomac River, where the average salinity is $14 \%$ oo the fungus was present at moderate levels of incidence. In the Rappahannock River the fungus is common at Hoghouse (15 $\%$ oo ) but rare at Morattico $\left(12 \% /{ }^{\circ}\right)$. It appears that the range of the fungus is controlled by factors other than salinity.

\section{Effects of Low Salinities on Infections}

Ready access to low-salinity waters where the disease is absent prompted us to transplant infected oysters to those areas for study. The James River Fleet Pier, an abandoned structure which extends out to the channel in an area where the salinity ranges from 1 to $13 \%$ was chosen for the low-salinity station. Oysters from Tray 16 at Gloucester Point, collected in the Rappahannock River in 1952 as yearlings and 2-yr-olds, were used in the experiment (Table 1). From June to October 1953 the death rate of these oysters in trays at Gloucester Point was $21 \%$. Most of the gapers removed from this tray in 1953 were heavily infected, and it is assumed that live oysters, which were not tested for the fung'us, had a high incidence of infection.

TABLE 9. Incidence and intensity of fungus in oysters exposed to infection then transplanted to a low-salinity area in the James River, 1954.

\begin{tabular}{|c|c|c|c|c|c|c|c|c|}
\hline \multirow{2}{*}{ 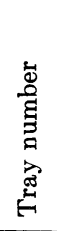 } & \multirow[b]{2}{*}{ 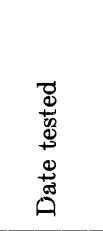 } & \multirow[b]{2}{*}{ 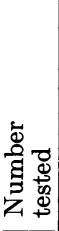 } & \multicolumn{4}{|c|}{$\begin{array}{l}\text { Number OF INFEC- } \\
\text { TIONS BY INTENSITIES }\end{array}$} & \multirow[b]{2}{*}{ 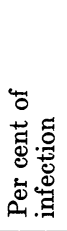 } & \multirow[b]{2}{*}{ 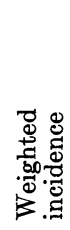 } \\
\hline & & & 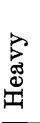 & 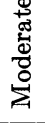 & 莺 & 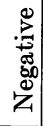 & & \\
\hline 16 & 5 Nov & 28 & 1 & 10 & 16 & 1 & 96 & 1.82 \\
\hline $16 \mathrm{a}$ & 30 Aug & 26 & & 1 & 5 & 20 & 2 & 0.31 \\
\hline $16 a$ & $5 \mathrm{Nov}$ & 27 & & 4 & 2 & 21 & 21 & 0.52 \\
\hline $16 \mathrm{~b}$ & $5 \mathrm{Nov}$ & 25 & 1 & 5 & 16 & 3 & 88 & 1.44 \\
\hline 31 & 27 Oct & 20 & & 8 & 4 & 8 & 60 & 1.40 \\
\hline 32 & $5 \mathrm{Nov}$ & 25 & & & & 25 & 0 & 0.00 \\
\hline
\end{tabular}

The first group of oysters (Tray 16A) was moved to the Fleet Pier on May 5, 1954. Tests of live oysters for the fungus were not made at this time, but it was known from the five series of monthly thioglycollate tests described earlier that infections were rare or absent in May. On August 30 it was found that 6 of 26 oysters in Tray $16 \mathrm{~A}$ were infected, and on November 5, 6 of 27 oysters were infected (Table 9). The death rate in the tray from May 5 to August 30 was $11.7 \%$. Six of the 7 deaths occul'red before June 14 and the one gaper recovered was negative for the fungus. There was no mortality in Tray 16A from August 30 to November 5.

The second group of oysters (Tray 16B) was moverl to the Fleet Pier on August 30, 1954. These oyster's, from Tray 16, had high death rates and many heavily-infected gapers in July and August. Again, live oysters were not tested when transplanted, but it is assumed from the intensity of infections in gapers that infections were common. On November 5 , all but 3 of 25 oysters were infected (Table 9 ), the mortality was high, and the two gapers which were recovered had heavy infections (Table. $10)$.

TABLE 10. Mortality rates of oysters exposed to the fungus then transplanted to a low-salinity area in the James River, 1954.

\begin{tabular}{|c|c|c|c|c|c|c|}
\hline \multirow{2}{*}{ Tray number } & \multicolumn{3}{|c|}{5 MAY - 30 August } & \multicolumn{3}{|c|}{30 August - 5 Nov. } \\
\hline & $\begin{array}{l}\text { Num- } \\
\text { ber } \\
\text { alive }\end{array}$ & $\begin{array}{c}\text { Num- } \\
\text { ber } \\
\text { dead }\end{array}$ & $\begin{array}{c}\text { Per } \\
\text { cent } \\
\text { dead }\end{array}$ & $\begin{array}{l}\text { Num- } \\
\text { ber } \\
\text { alive }\end{array}$ & $\begin{array}{c}\text { Num- } \\
\text { ber } \\
\text { dead }\end{array}$ & $\begin{array}{l}\text { Per } \\
\text { cent } \\
\text { dead }\end{array}$ \\
\hline $\begin{array}{l}16 \ldots \ldots \\
16 \mathrm{a} \ldots \ldots \\
16 \mathrm{~b} . \ldots \\
31 \ldots \ldots \\
32 \ldots \ldots\end{array}$ & $\begin{array}{r}122 \\
60 \\
\ddot{5} \dot{3} \\
177\end{array}$ & $\begin{array}{r}45 \\
7\end{array}$ & $\begin{array}{l}36.9 \\
11.7 \\
\ldots .0 \\
0.0 \\
9.0\end{array}$ & $\begin{array}{r}40 \\
27 \\
37 \\
43 \\
159\end{array}$ & $\begin{array}{r}13 \\
0 \\
13 \\
2 \\
8\end{array}$ & $\begin{array}{r}32.5 \\
0.0 \\
35.1 \\
4.7 \\
5.0\end{array}$ \\
\hline
\end{tabular}

One of the control groups (Tray 16) consisted of the remaining oysters at Gloucester Point. At the end of the high mortality period, all but one of these oysters were infected and the death rate was high before and after August 30 (Tables $9 \& 10$ ).

The other control group (Tray 32) consisted of fungus-free oysters which had been in trays at the Fleet Pier since the summer of 1953. None of these oysters had infections in November 1954 (Table 9). The mortality was low for the early and late summer periods, and most of the deaths from May to August were caused by smothering when the tray fell into the bottom mud (Table 10).

Another group of disease-free oysters (Tray 31) was moved from the Fleet Pier to Gloucester Point on August 30. No tests of live oysters were made at this time but their history was identical with that for Tray 32 and it is assumed they had no infections when moved. On October 27 these oysters had developed a substantial number of infections with a weighted incidence almost as high as the control group (Tray 16).

It appears that infections, once established, can persist in low salinity waters without eausing many deaths. In 1954 trays of infected and uninfected oysters were held in close proximity at the James River Fleet Pier through the summer without causing infections in the disease-free oysters. Since established infections persisted and slowly increased in intensity, it is presumed that failure of oysters to acquire new infections was probably due to the absence or scarcity of infective spores. There are indications that the low salinity retarded the development of the disease from overwintering infections (Tray 16A) but that the death rate was not reduced among oysters with substantial infections (Tray 16B). Probably of greatest importance is the evidence that almost $25 \%$ of the oysters in Tray 16 carried infections through the winter. Such overwintering infections usually give negative results with the thioglycollate test. 
In 1955 another attempt was made to determine the extent of overwintering of the fungus. At the James River Fleet Pier, 450 oysters from Hoghouse Bar, an infested area, and 200 local fungusfree oysters were placed in trays. Very few of the oysters died before mid-August when the Hurricanes Connie and Diane passed. In late August after the passage of the hurricanes, mortalities caused by fresh water and its associated effects were experienced on oyster grounds in each of the three major rivers in Virginia. On August 30, over half of the Hoghouse oysters in trays at the Fleet Pier were dead and over one-fourth of the local oysters had died. All but 50 of the Hoghouse oysters were dead on September 24 and only 88 of the local oysters remained alive. However, losses at Deep Water Shoal, a natural bar one mile above the Fleet Pier, were much less severe than in the trays. The cause of the excessive death rate of Hoghouse and local oysters in trays at the Fleet Pier remains a mystery. Even more baffling was the absence of $D$. marinum infections in 75 gapers and 37 live oysters from the trays of Hoghouse oysters. As expected, 25 live oysters and 10 gapers from the tray of local oysters exhibited no infections.

\section{ReCapitulation}

Although the limits of the distribution of the fungus in Chesapeake Bay are conveniently associated with the isohaline of $15 \%$, salinity in itself is apparently not an effective limiting factor. The fungus does not produce new infections in low salinity waters and development is merely retarded when infected oysters are moved to such waters.

\section{THE EFFECTS OF HANDLING AND OTHER FACTORS ON FUNGUS INFECTIONS}

\section{EFfects of Handling on Fungus Infections}

Frequent handling or removal from the water for extended periods might be expected to increase the death rate of oysters. The handling of oysters in trays was described in an earlier paper (Hewatt \& Andrews 1954b). Except for occasional cleaning, oysters in trays were exposed only about five minute; daily while gapers were sought.

An experiment was conducted in 1955 to compare the effects of handling oysters daily and monthly. About 1000 market oysters were dredged from Hoghouse Bar, an infested area in the Rappahannock River, and divided into two lots, each of which occupied three trays. The first lot of oysters, Trays 56 to 58, was examined daily, and the second lot, Trays 59 to 61 , monthly. In all other respects the trays were treated alike.

The death rate in Lot 1 was less than in Lot 2, although not significantly so. Therefore, there is no evidence that daily handling increased mortalities (Table 11). The data again raise the question of tray-to-tray variability, already examined in the section on source and age differences (Table 7). It
TABLE 11. The effect of frequency of handling on the death rate of oysters in trays, 1955 .

\begin{tabular}{|c|c|c|c|c|c|c|c|c|}
\hline \multirow{2}{*}{ Month } & \multicolumn{4}{|c|}{$\begin{array}{c}\text { Number Dead in } \\
\text { Lot 1, Examined } \\
\text { Daily }\end{array}$} & \multicolumn{4}{|c|}{$\begin{array}{c}\text { Number Dead in } \\
\text { Lot 2, Examined } \\
\text { MoNThly }\end{array}$} \\
\hline & 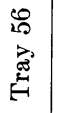 & 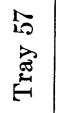 & 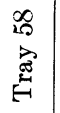 & $\begin{array}{l}\bar{T} \\
\stackrel{T}{0} \\
\stackrel{0}{0}\end{array}$ & 疍 & 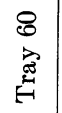 & 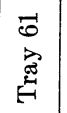 & 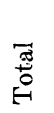 \\
\hline $\begin{array}{l}\text { June. . . . . . . . . . } \\
\text { July . . . . . . . . } \\
\text { August. . . . . . . } \\
\text { September. . . . . } \\
\text { October . . . . . . }\end{array}$ & \begin{tabular}{r|}
2 \\
2 \\
17 \\
8 \\
10
\end{tabular} & \begin{tabular}{r|}
1 \\
9 \\
8 \\
12 \\
10
\end{tabular} & $\begin{array}{r}1 \\
5 \\
13 \\
13 \\
5\end{array}$ & $\begin{array}{r}4 \\
16 \\
38 \\
33 \\
25\end{array}$ & $\begin{array}{r}1 \\
11 \\
9 \\
14 \\
15\end{array}$ & \begin{tabular}{r|}
1 \\
4 \\
12 \\
5 \\
10
\end{tabular} & $\begin{array}{r}1 \\
6 \\
16 \\
18 \\
16\end{array}$ & $\begin{array}{r}3 \\
21 \\
37 \\
37 \\
41\end{array}$ \\
\hline Total. & 39 & 40 & 37 & 116 & 50 & 32 & 57 & 139 \\
\hline $\begin{array}{l}\text { Original count } \ldots \ldots \\
\text { Death rate } \\
\quad(\text { per cent }) \ldots \ldots\end{array}$ & $\begin{array}{r}170 \\
23\end{array}$ & $\begin{array}{r}182 \\
22\end{array}$ & $\begin{array}{r}168 \\
22\end{array}$ & $\begin{array}{r}520 \\
22\end{array}$ & $\begin{array}{r}174 \\
29\end{array}$ & $\begin{array}{r}161 \\
20\end{array}$ & $\begin{array}{r}180 \\
32\end{array}$ & $\begin{array}{r}5 \mathrm{i} 5 \\
27\end{array}$ \\
\hline \multicolumn{5}{|c|}{$\begin{array}{c}\chi^{2}=0.10 \\
\mathrm{P}=0.95 \quad 2 \text { d.f. }\end{array}$} & \multicolumn{4}{|c|}{$\begin{array}{c}\chi^{2}=5.58 \\
\mathrm{P}>0.05 \quad 2 \text { d.f. }\end{array}$} \\
\hline
\end{tabular}

$\chi^{2}$ test of lots 1 and $2=2.97 \quad \mathrm{P}=0.10 \quad 1$ d.f.

is our belief, after five years of tray experiments, that, over a period of several months or a year, samples as small as 100 oysters usually give reliable death rates. If the true death rate for oysters in the handling experiment is assumed to be $25 \%$, the observed death rate in each tray falls within the $95 \%$ confidence interval of 18 to $33 \%$ (Table 11). Mortalities in the trays of Lot 1 were remarkably similar but these of Lot 2 varied considerably. Although significant differences in the death rates between lots were not confirmed by chi-square tests, the removal of gapers from Lot 1 is a factor to consider. Over $90 \%$ of the gapers were removed from Lot 1 before much disintegration had occurred, but in Lot 2 nearly all gapers disintegrated and by releasing: fungus spores may have accelerated the infections in neighboring oysters. It will be noticed that as the warm season progressed deaths continued to increase in Lot 2 but decreased in Lot 1 . For the month of October alone, the death rate was $9.8 \%$ in Lot 2 and only $5.8 \%$ in Lot 1.

From each tray 25 live oysters were tested for the fungus. The oysters handled daily had fewer infections and intensities were lower than those examined monthly (Table 12), but again these differences were not significant. Within each lot variations in the number of infections and the weighted incidence were small, and the data on fungus infections do not explain the low mortality in Tray 60 , or the high mortality in Tray 61 . Few gapers were recovered from the monthly trays but these usually had heavy infections. From the two lots, 124 gapers were recovered, of which $96 \%$ were infected and the weighted incidence was 4.5 ; hence there is little question that most deaths in both lots occurred from fungus infections. 
TABLE 12. The effects of frequency of handling on fungus infections in tray-grown oysters, 1955.

\begin{tabular}{|c|c|c|c|c|c|c|c|c|}
\hline \multirow[b]{2}{*}{ 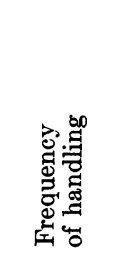 } & \multirow[b]{2}{*}{ 琣 } & \multirow{2}{*}{ 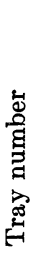 } & \multicolumn{4}{|c|}{$\begin{array}{c}\text { NUMBER OF INFEC- } \\
\text { TIONS BY } \\
\text { INTENSITIES }\end{array}$} & \multirow[b]{2}{*}{ 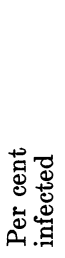 } & \multirow[b]{2}{*}{ 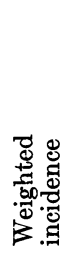 } \\
\hline & & & 定 & 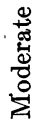 & 蒙苟 & 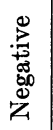 & & \\
\hline \multirow[t]{2}{*}{ Daily } & $\begin{aligned} 5 & \text { Nov } \\
7 & \text { Nov } \\
12 & \text { Nov }\end{aligned}$ & $\begin{array}{l}56 \\
57 \\
58\end{array}$ & $\begin{array}{l}2 \\
0 \\
0\end{array}$ & $\begin{array}{l}0 \\
7 \\
6\end{array}$ & $\begin{array}{r}15 \\
7 \\
14\end{array}$ & $\begin{array}{r}8 \\
11 \\
5\end{array}$ & $\begin{array}{l}68 \\
56 \\
80\end{array}$ & $\begin{array}{l}1.00 \\
1.12 \\
1.28\end{array}$ \\
\hline & $\begin{array}{l}\text { Totals } \\
\text { Averages }\end{array}$ & & 2 & 13 & 36 & 24 & 69 & 1.13 \\
\hline \multirow[t]{2}{*}{ Monthly } & $\begin{aligned} 5 & \text { Nov } \\
7 & \text { Nov } \\
12 & \text { Nov }\end{aligned}$ & $\begin{array}{l}59 \\
60 \\
61\end{array}$ & $\begin{array}{l}1 \\
2 \\
0\end{array}$ & $\begin{array}{l}4 \\
3 \\
8\end{array}$ & $\begin{array}{l}18 \\
15 \\
12\end{array}$ & $\begin{array}{l}2 \\
5 \\
5\end{array}$ & $\begin{array}{l}92 \\
80 \\
80\end{array}$ & $\begin{array}{l}1.40 \\
1.36 \\
1.44\end{array}$ \\
\hline & $\begin{array}{l}\text { Totals } \\
\text { Averages }\end{array}$ & & 3 & 15 & 45 & 12 & 84 & 1.40 \\
\hline
\end{tabular}

A third lot of oysters from Hoghouse Bar was placed in trays on a planted oyster ground near Gloucester Point in water having a depth of five feet at mean low tide. Special trays with legs were built to raise the oysters approximately one foot off the bottom. The two trays, containing 473 oysters, were examined six times during the summer and fall and the death rate from June to November was $i 7.8 \%$. This is significantly lower (Chi-square= $12.30, \mathrm{df}=2, \mathrm{P}=<0.01$ ) than the mean rate of $22.5 \%$ for all Hoghouse oysters in trays at the Laboratory pier (Table 13).

TABLE 13. Chi-square tests for differences in death rates of Hoghouse oysters in trays, 1955.

\begin{tabular}{l|l|l|r|r|r|r|r}
\hline \hline $\begin{array}{c}\text { Tray } \\
\text { numbers }\end{array}$ & Location & Handling & $\begin{array}{c}\text { Num- } \\
\text { bers } \\
\text { in } \\
\text { group }\end{array}$ & $\begin{array}{c}\text { Num- } \\
\text { bers } \\
\text { of } \\
\text { dead }\end{array}$ & $\begin{array}{c}\text { Mortality } \\
\text { in per } \\
\text { cent }\end{array}$ & $\chi^{2}$ & P \\
\hline 56 to 58 & VFL pier & Daily & 520 & 116 & 22.3 & & \\
59 to 61 & VFL pier & Monthly & 515 & 139 & 27.0 & 12.30 & $<0.01$ \\
63 \& 65 & Natural bed & Monthly & 473 & 84 & 17.5 & & \\
& & 1508 & 339 & & & \\
\hline
\end{tabular}

\section{Viability of Fungus Spores}

The viability of fungus spores was tested by various severe treatments. On August 16, 1955, half of each of the meats from 5 heavily-infected gapers were frozen and pieces of each, tested by the thioglycollate method each day until September 3, remained heavily infected throughout the 18-day period. In another experiment beginning August 16, the remaining halves of each of these 5 gapers were homogenated in a small amount of sea-water with a Waring blendor, and held at room temperatures. Daily testing revealed heavy infections on August 17 and 18, moderate infections on the 19th and 20th, light to very light infections on the 21st and 25th, and no infections thereafter. "In homogenated tissues, the spores persisted for 9 days. In another experiment, three heavily-infected gaper meats were placed in Petri dishes without water on August 3, and held at room temperatures; on September 3 tissues from all were still heavily infected. Similarly, gaper meats held in salt water in finger bowls at room temperatures retained their level of fungus infection for periods of 16 and 25 days despite nearly complete disintegration. It appears that spores within the oyster tissues can persist for long periods but that they are rapidly destroyed when released into the water.

\section{ReCaPitulation}

Trays from which gapers were removed daily had slightly lower mortalities than trays examined monthly. The death rates in trays over planted grounds were lower than at the Laboratory pier. The incidences and intensities of fungus infections were somewhat higher in the oysters examined monthly. In general these data support the conclusion that a tray of 100 to 200 oysters will give a fairly reliable estimate of the death rate and the level of fungus infections. The fungus withstands freezing and drying of oyster tissues but is rapidly destroyed in homogenated tissues.

\section{DISCUSSION AND CONCLUSIONS}

The Importance of Dermocystidium marinum AS a Cause of Oyster Disease

Most diseases are limited in their ravages of host populations by one or more factors such as seasonal occurrence, mode of transmission, range, and pathogenicity. D. marinum is highly pathogenic to oysters and has an extensive range in Chesapeake Bay. Only the short season of disease activity prevents catastrophic losses among oysters. Most oysters growing in areas infested with the disease probably have the fungus during their lifetime, and apparently all are susceptible if conditions are favorable for the disease. It is not unusual for $75 \%$ of the oysters in a bed to have the disease in one summer and most oysters remain on the growing grounds two or three summers.

Most oyster grounds in Virginia are affected by the fungus. Evidently the water-borne spores are distributed widely and only rarely was the disease absent in local areas within the range of the fungus. Not even oyster drills, the scourge of young oysters, range as widely. The James River seed area and Seaside of the Eastern Shore are the only major areas essentially free of fungus infections. Creeks and the uppermost oyster-producing grounds of river estuaries constitute the remainder of the diseasefree grounds. In Maryland, on the other hand, the fungus is limited to a small portion of the oyster grounds.

Dermocystidium has been the primary cause of 
death in about $87 \%$ of the gaping tray oysters examined by us in the past four years. This is assuming that all gapers with heavy and moderate infections were killed by the fungus. If only the heavily-infected oysters are considered, still about $81 \%$ of all deaths can be attributed to the disease. It is easy, however, to place too much importance on the disease if only tray studies are considered. The fungus is the dominant killer in trays because smothering, injury, drill predation and other causes of death associated with natural bottoms are prevented. On natural grounds some of these agents of death take their toll before oysters become large enough to be attacked by the fungus, and interact with the fungus thereafter. The fungus causes disease mostly in large oysters two years of age and older.

The fungus probably affects the condition and growth of oysters (Menzel \& Hopkins 1955). Ray, Mackin \& Boswell (1953) reported that the mean wet weights of heavily-infected oyster meats were about $33 \%$ less than those of uninfected oysters. In Virginia, however, we have repeatedly noticed that in late summer some heavily-infected gapers appear to be fatter than live oysters. Measurements have not been made to confirm this impression, but it is possible that differences in spawning and fattening cycles between Gulf of Mexico and Chesapeake Bay oysters may influence the effects of the disease on condition. The color and plumpness of some gapers may be the result of failure to spawn. Perhaps the rapidity of development of the disease in August and September leads to death before emaciation. Many gapers in extremely poor condition are also encountered.

Our estimate of the importance of the fungus on commercial oyster grounds is based on the similarity of infections in live oysters from trays and from natural habitats, and the demonstration that heavilyinfected gapers do occur on natural grounds. The series of monthly tests at Gloucester Point demonstrated that in a given area the type of habitat did not greatly influence the level or seasonal pattern of infections in live oysters. In gapers, however, those from natural habitats usually had lower incidences of fungus infections than those from trays. This implies that other factors were causing deaths on natural grounds. The incidence of infection seemed to be particularly low in gapers collected from dredge boats where the dredging operation may have been the cause of the injury. Gapers are hard to find on natural bottoms, and when they occur with high frequency abnormal conditions usually are indicated.

The actual losses on natural grounds from Dermocystidium have not been determined. In three years, annual losses in trays at Gloucester Point have varied from 26 to $57 \%$ in native oysters over two years of age, and about $87 \%$ of the deaths can be attributed to the fungus. In 1954, the average an- nual mortality for oysters in trays at Gloucester Point was over $50 \%$, and on a commercial bed which yielded only one-half bushel per bushel of oysters planted, marked oysters on the bottom had a mortality of $61 \%$. This was a year of great fungus activity, and the association with high oyster losses strongly implies a major role for the fungus on natural grounds. Unfortunately, the severe hurricane, Hazel, which struck in mid-October 1954, was promptly allotted a major share of the blame for poor yields.

\section{Dissemination of Fungus Spores and Relation TO SALINITIES}

The dissemination of spores is a subject of great importance about which little is known, for no one has collected spores from natural waters or demonstrated their presence. Spores are released in the water by the various tissue-destroying agents acting on gapers. In aquaria, we have found numerous spores in the spawn of infected oysters. Spores are expected in the fecal material of oysters, but they have been hard to demonstrate by the thioglycollate culture method. The relative importance of spores from disintegrating gapers, spawn, and fecal material is unknown, but probably the gapers provide most of the spores released in the water. Some of the scavengers feeding on gaper meats, particularly nereid worms, have the fungus spores in their tissues, and they may serve as distributors and temporary hosts for the spores. Mackin (1956) has recently described a life cycle for $D$. marinum, partly-hypothetical, which includes many stages, all of which are believed to be infective. This greatly complicates the study of the dissemination of infective elements.

The effects of proximity of oysters in spreading fungus infections have been studied by Ray (1954c) in aquaria, but little is known of this factor in natural waters. Oysters may be more densely arranged in trays than on planted grounds, and the removal of gaper meats may be quicker on natural bottoms where all scavengers have access to the oysters. In the experiments on handling of oysters, gapers were removed from the daily trays, but the slightly higher incidences and intensities of the fungus in the monthly trays, in which gapers were allowed to deteriorate, were not statistically significant. If there is a proximity effect, the disease may be more severe on thickly planted private grounds than on sparsely populated public grounds. Hoghouse Bar, a public ground in the Rappahannock River, was consistently low in the incidence of the fungus, but salinities at this station were also low and may have restricted the number of infections.

The occurrence of the fungus on nearly every oyster ground examined in the lower half of Chesapeake Bay led us to believe that the spores were widely distributed by water currents. Recently, a discontinuous distribution of the fungus has been reported in lower Delaware Bay (personal com- 
munication, New Jersey Oyster Research Laboratory, Rutgers University). Locales of high infection have been associated with imports of Virginia seed-oysters. These observations suggest that the disease spreads gradually over oyster grounds and not through wide dispersal of spores by water eurrents.

The experiments involving the transplantation of infected oysters to low-salinity waters suggest that infective elements are dispersed or destroyed too quickly to increase infections by contiguity of oysters. In these experiments, infected oysters were placed in a tray within a few feet of disease-free oysters but no infections occurred. High-salinity waters may be more favorable for free spores, and proximity to diseased oysters may then enhance infections. The positive response of $D$. marinum spores to thioglycollate treatment after being frozen or dried in gapers for several days, and the quick disappearance of spores in homogenated tissues are interesting clues to the persistence and dispersal of spores in open waters. Mackin (personal communication) states that bacteria attack the spores quickly after the death of the oyster and that most spores in homogenated tissues are dead by the eighth day.

The absence of infections in low-salinity water; may indicate a lack or scarcity of spores. The most probable explanation, advanced by Mackin and supported by Ray (1954a), is that spores are dispersed and carried down the estuaries through the addition of fresh water. The disease persists and intensifies in infected oysters transplanted to lowsalinity areas. We agree with Mackin (1956) and Ray (1954c) that low salinity per se appears to have little effect on the distribution of the fungus, although it may delay development of the disease and suppress mortalities. We suspect that the circulation pattern and the flushing characteristics of a body of water are of primary importance in regulating the disease pattern. In Virginia the incidence of D. marinum appears to be lowest where the flushing rate is greatest. The James River with vigorous flushing has little fungus although summer bottom salinities at the James River Bridge usually have a mean of about $17 \%$ oo. In Chesapeake Bay salinities do not vary much in the summer and fall seasons when Dermocystidium is most active. The relative stability of flushing patterns, which is reflected in salinity patterns, probably lends regularity to the fungus disease picture.

The problem of the dissemination of spores deserves more study, for if infections should be localized and produced by proximity to infected oysters, then there exists a basis for practical control by avoiding infected seed-oysters and thoroughly cleaning all oysters from planting grounds.

\section{Variations of Infections with Age and Source of Oysters}

The absence of the fungus in oysters growing in Seaside and Chincoteague waters has intrigued us. The high salinities and temperatures of these areas are comparable to those of lower Chesapeake Bay, and should provide suitable habitats for the fungus. Furthermore, oysters have been transplanted back and forth between these areas and Chesapeake Bay, offering numerous opportunities for the fungus to become established. No explanation for this anomaly can be offered at present.

The susceptibility of Seaside oysters and the resistance of South Carolina oysters to D. marinum leads one to a comparison of their habitats. In both areas most oysters grow intertidally in waters of high salinity. Can the differences in susceptibility of the oysters be explained in terms of the period of time the fungus has been present in each area, and have southern oysters undergone a period of selection toward natural immunity? If so, this could mean that the fungus has moved or is moving north along the Atlantic coast.

Ray (1954a) studied the effects of D. marinum on young oysters in Barataria Bay and found spat refractive to infections until an age of three or four months was reached. Thereafter susceptibility increased into the second year. In infested waters of Chesapeake Bay, a few oysters became infected a: yearlings, and apparently susceptibility of oysters increases to an age of about three years. Since the fungus responds to high temperatures, in comparing Barataria Bay and Chesapeake Bay consideration must be given to the duration of the warm season. In the Gulf of Mexico the oyster is active most of the year whereas in Chesapeake Bay it is dormant for several months. Consequently, market size is attained in 18 to 24 months in the Gulf but 24 to 36 or more are required in Chesapeake waters. Therefore, in the two areas, oysters of the same age are not necessarily of the same size. The size of oysters may be an important factor affecting the occurrence of $D$. marinum infections.

\section{Effects of the Disease on the Oxster Industry in Chesapeake Bay}

The epidemiology of the disease in Virginia differs from that described for Louisiana chiefly by the shorter period of pathogenicity to oysters. The disease remains active for most of the year in Barataria Bay, Louisiana, but it is dormant nearly half the year in Virginia. In Virginia, infections almost disappear in winter and spring, whereas in Louisiana intensities decline but incidences remain high. Annual fluctuations in the intensity of the disease, and the damage caused by it, seem to be related to the level and duration of temperatures and to water circulation as influenced by rainfall. Hot and dry summers, particularly when these conditions are prolonged into the fall, favor the disease.

Ray (1954c) has discussed the importance of fresh water and low salinity areas in controlling the disease. $\mathrm{He}$ also suggests full utilization of young oysters under one year of age in which incidence of the disease is low. In Chesapeake Bay, control of the 
fungus seems unlikely at present, but proper management may minimize losses. The fungus is present in nearly all beds of oysters within its range. The duration of the disease preceding the death of an oyster may be as short as one month, and it does not appear practical to treat individuals or groups of oysters for the disease. At present, reduction of losses depends upon avoiding the fungus. Low salinity waters where the disease is not present should be fully used and the number of summers during which oysters are held in high salinity waters should be strictly limited.

In Louisiana the entire crop of oysters over a year of age is often lost during one summer (Ray \& Chandler 1955). Oysters may be held two or three summers in Virginia before the yield is reduced to a level which returns no profit. Nevertheless, it is strongly recommended in areas where the disease flourishes that oysters be held only the minimal number of summers necessary to reach market size. This can be accomplished by planting the largest uninfected oysters available and harvesting the stock as soon as it becomes satisfactory for standard oysters. Attempts to raise barrel stock (oysters retailed in the shells) or a large proportion of selects (large choice oysters) in infested areas probably will fail. Planting oysters in shallow waters of creeks endemic for the disease is particularly hazardous because water temperatures reach high levels, and slow flushing maintains high concentrations of spores. The high susceptibility of Seaside oysters almost precludes their use in infested areas unless satisfactory growth can be obtained with only one summer season of exposure to the fungus. The high death rates of Seaside seed oysters during their second and third summers in Chesapeake Bay have long been known to oystermen, but only now is the cause known to be Dermocystidium. In the Bay it probably will be advantageous to plant in early fall in infested areas to take advantage of fall and spring growth before infections occur during the first summer. We believe that the best yields will be obtained by late spring harvesting. McHugh \& Andrews (1955) have shown that tray-grown oysters in areas infested with the disease may reach their maximum total biomass in about 18 to 24 months after transplanting. During each year, the yield reaches a peak in late spring and declines during the summer and fall. After the second summer in waters containing the fungus, growth fails to equal losses and yield declines. This further emphasizes the necessity to limit the number of summers or warm periods through which oysters are held.

The development of resistant stock may be the most desirable method of combatting the disease. Seed areas in low salinity waters, for example the James River, are free of the disease, therefore naturai selection for resistance to the disease will probably be slow in Chesapeake Bay. There is evidence already that native oysters in infested areas are more resist- ant than James River seed. The most resistant oysters encountered were those obtained from South Carolina. The practicability of importing seed in commercial quantities from South Carolina is not yet established, and since South Carolina seed has certain disadvantages which must be explored further, it is chiefly useful now for experimental purposes.

Natural selection for resistant oysters in areas where the disease is active is slow because the native brood stock is restricted by poor reproduction and heavy predation of young oysters. The rapidity of natural selection depends to some extent upon the pathogenicity of the disease. In Prince Edward Island, Canada, the Malpeque disease killed most of the oysters in a relatively short time (Needler \& Logie 1947). The survivors, which may have been oysters imported from the northern shores of the United States, became the principal brood stock in the area, and soon the population offered considerable resistance to the disease. In Chesapeake Bay many oysters, including planted oysters from the James River seed area, live two or three years before $D$. marinum strikes, and they breed and perpetuate their kind successfully. Presumably selection would be more rapid in areas like the Gulf of Mexico where mortalities are extremely high each year.

It may be possible to produce limited quantities of selected brood stock in tanks or in enclosed ponds. Selected brood stock resistant to the disease would have little chance of becoming effective in the James River seed area among voluminous stocks of native oysters which are not undergoing selection. However, limited quantities of resistant stock might become effective in disease-infested areas if protection from predation could be obtained for the progeny.

There is no proof that the disease was present in Chesapeake Bay prior to 1949 . Until there is evidence of recent introduction, however, we must assume that it has been present for many years and that oystermen do not have a new source of mortality with which to contend.

\section{The Role of Other Parasites and Pests in Oyster Mortality}

In addition to $D$. marinum, which has been studied most intensively because of its role as a major cause of oyster deaths, other pests and parasites have been considered in relation to oyster mortality. The discovery of Dermocystidium-like organisms in numerous species of bivalves raised the problem of host specificity. Cross-infection experiments, although not yet tried on all bivalves with fungus parasites, have failed to produce evidence of conspecificity, and even when the host is abused anil weakened, none of the parasites in bivalves other than the oyster appears to cause serious infections. The high incidence and low intensity of infections in many bivalves is striking. It appear's quite obvious from the occurrence of large clusters of cells in the tissues that the fungi in these other bivalves have multiplied in the hosts. However, large numbers 
of fungus cells have also been seen repeatedly in the parapodia of marine annelids, Neanthes succinea (Frey \& Leuckart), which have fed on oyster gaper tissues.

After attempting cross-infection experiments, Ray (1954c) concluded that a considerable degree of host specificity existed. Mackin studied sections of clams and states (personal communication) that the parasites in Macoma are not D. marinum. It is possible that a whole group of related species of fungus parasites of bivalve mollusks is involved. In some species of bivalves, the parasites were found in Chesapeake Bay but not in the Gulf of Mexico (Ray 1954c). At present there is no evidence that these parasites of other bivalves play a role in the destruction caused by $D$. marinum in oysters.

Organisms which may be contributing factors in fungus-caused deaths of oysters are the gregarine, Nematopsis, the mud-blister worm, Polydora, and the boring sponges. Nematopsis has rarely been abundant in gaper tissues examined during this study and probably has not contributed to the deaths of oysters in trays. Polydora is believed to be the primary cause of deaths in a few oysters and probably is a contributing factor in the deaths of others; similar results were obtained by Mackin \& Cauthron (1952) in Louisiana. Closed and open abscesses located in ealcified or soft protuberances arising from the shell are not uncommon. These projections or "mud pearls," caused by the activities of worms which have penetrated the shell in the area of muscle attachments, displace the muscle tissues and weaken oysters. Mud pearls are most common in late fall and winter gapers. Most gapers containing such obstructions are infected with the fungus, but some are not, and these may have been killed by Polydora. Although boring sponge was abundant in the shells of many tray oysters, the effect on the death rate appears to be slight. Oysters with heavy infestations of the sponge have been held in trays at Gloucester Point for five years.

During the cool spring months each year, and particularly in May and June, South Carolina oysters had a low but persistent death rate not found in native oysters. These deaths were not caused by Dermocystidium and it is possible in these oysters introduced from southern areas that cool weather diseases, such as Hexamitiasis, are active (Mackin, Korringa \& Hopkins 1952). Other diseases as yet undescribed are believed to occur in Virginia oysters (Mackin, personal communication).

\section{SUM.MARY}

The problem of mortality of oysters in Virginia waters has been approached by studying oysters in trays suspended off the bottom. This method eliminates many death-producing agents related to bottom conditions. In a previous paper (Hewatt \& Andrews 1954) the seasonal pattern of mortality in trays was described. In this report, the epidemiology of one of the most important agents of death, the disease caused by the fungus, Dermocystidium marinum, is discussed. Attempts have been made to relate mortalities in trays to those on natural bottoms, but this important phase of the work requires further study.

In live oysters the fungus flourishes in the warm seasons and either becomes dormant or disappears during the cold seasons. At Gloucester Point, 70 to $100 \%$ of all acclimated oysters two years of age and older, whether from trays or natural bottoms, became infected each summer and fall, and live oysters from other areas revealed comparable infections.

Gapers (dying oysters) were collected mostly from trays at Gloucester Point. During the years 1952 to 1955,89 to $95 \%$ of all gapers were infected, and most of these had heavy concentrations of the fungus spores in all tissues. Mackin has demonstrated that such infections are lethal to oysters. In trays nearly all deaths occurred during the warm months of summer and fall and a high percentage of these were caused by the fungus. Gapers without fungus infections were always rare but occurred most commonly in late winter and spring.

Each summer the incidence of infections became high both in live oysters and gapers but the intensity was much higher in gapers; most live oysters had light and most gapers heavy infections. It is concluded that the fungus disease is highly pathogence to Chesapeake Bay oysters and that only the relatively short warm season prevents higher death rates.

The age and source of oysters influenced the occurrence of the fungus and the death rate. Yearling oysters had few infections and low death rates in natural waters, but they were easily infected and killed experimentally by feeding minced gaper tissues. Both the level of infection and the death rate increased with age until oysters were three years old. Infections and deaths were more frequent in oysters from Seaside of the Eastern Shore and less frequent in oysters from South Carolina than in native Chesapeake Bay oysters. Racial differences in susceptibility to the disease are indicated.

Tests of live oysters revealed the presence of the disease in most Virginia waters except the James River seed area, Seaside of Eastern Shore, Chincoteague Bay, the Potomac River and its tributaries. and the creeks and extreme upper limits of the other major rivers. The disease was usually absent in areas with summer salinities below $15 \%$ oo. The absence of the disease in the high salinity waters of Seaside has not yet been explained.

The disease flourishes at high temperatures and prefers moderate and high salinities. Established infections are inhibited at temperatures below $15^{\circ}$ $\mathrm{C}$ and salinities below 12 to $15 \%$ oo but spores within oyster tissues are resistant to freezing and drying. Groups of oysters fully acclimated to areas where the disease is active develop infections earlier in the season, and eventually have a higher percentage of 
serious infections than oysters transplanted from disease-free areas. This "acclimation effect" is believed to be related to overwintering infections in oysters. Warm winters followed by hot dry summers produce high mortalities. Daily handling of oysters in trays did not increase infections or deaths.

The disease reduces yields of oysters in lower Chesapeake Bay. Losses can be minimized by limiting the number of warm seasons that oysters are held in areas where the disease is endemic. Maximum use of low salinity areas is advisable. Seed oysters from Seaside of the Eastern Shore, which are more susceptible to the disease than natives, should not be used in Chesapeake Bay. Knowledge of expected losses will also aid the oysterman in planning his operations.

The role of other parasites and pests as mortalityproducing agents appears to be minor in traygrown oysters.

\section{LITERATURE CITED}

Andrews, J. D. 1955. Notes on fungus parasites of bivalve mollusks in Chesapeake Bay. Proc. Nat. Shellfisheries Assoc. 45: 157-163.

Andrews, J. D. \& W. G. Hewatt. 1954. Incidence of Dermocystidium marinum Mackin, Owen, and Collier, a fungus disease of oysters, in Virginia. Convention Addresses Nat. Shellfisheries Assoc. 1950 : 79 (Abstract).

Hewatt, W. G. \& J. D. Andrews. 1954a. Mortalities of oysters in trays at Gloucester Point, York River, Virginia. Convention Addresses Nat. Shellfisheries Assoc. 1953: 78 (Abstract).

Hewatt, W. G. \& J. D. Andrews. 1954b. Oyster mortality studies in Virginia. I. Mortalities of oysters in trays at Gloucester Point, York River. Texas Jour. Sei. 6: $121-133$.

Hewatt, W. G. \& J. D. Andrews. 1956. Temperature control experiments on the fungus disease, Dermocystidium marinum, of oysters. Proc. Nat. Shellfisheries Assoc. 46: 129-132.

Mackin, J. G. 1951. Histopathology of infection of Crassostrea virginica (Gmelin) by Dermocystidium marinum Mackin, Owen, and Collier. Bull. Mar. Sci. Gulf and Caribbean 1: 72-87.

- 1953. Incidence of infection of oysters by Dermocystidium in the Barataria Bay area of Louisiana. Convention Addresses Nat. Shellfisheries Assoc. 1951: 22-35.

- 1956. Dermocystidium marinum and salinity. Proc. Nat. Shellfisheries Assoc. 46: 116-128.

Mackin, J. G. \& J. L. Boswell. 1956. The life eycle and relationships of Dermocystidium marinum. Proc. Nat. Shellfisheries Assoc. 46: 112-115.
Mackin, J. G. \& F. F. Cauthron. 1952. Effect of heavy infestations of Polydora uebsteri Hartman on Crassostrea virginica (Gmelin) in Louisiana. Convention Addresses Nat. Shellfisheries Assoc. 1952: 14-24.

Mackin, J. G., P. Korringa \& S. H. Hopkins. 1952. Hexamitiasis of Ostrea edulis L. and Crassostrea virginica (Gmelin). Bull. Mar. Sci. Gulf and Caribbean 1: $266-27 \overline{5}$.

Mackin, J. G., H. M. Owen, \& A. Collier. 1950. Preliminary note on the occurrence of a new protistan parasite, Dermocystidium marinum n.sp. in Crassostrea virginica (Gmelin). Science 111: 328-329.

McHugh, J. L. \& J. D. Andrews. 1955. Computation of oyster yields in Virginia. Proc. Nat. Shellfisheries Assoc. 45: 217-239.

Menzel, R. W. \& S. H. Hopkins. 195う. The growth of oysters parasitized by the fungus Dermocystidium marinum and the trematode Bucephalus cuculus. Jour. Parasitol. 41: 333-342.

Needler, A. W. H. \& R. R. Logie. 1947. Serious mortalities in Prince Edward Island oysters caused by a contagious disease. Trans. Roy. Soc. Canada 41: $73-89$.

Cwen, H. M. 1953. The relationship of high temperatures and low rainfall on oyster production in Louisiana. Bull. Mar. Sci. Gulf and Caribbean 2: 34-43.

Pritchard, D. W. 1952. Salinity distribution and circulation in the Chesapeake Bay estuarine system. Jour. Mar. Res. 11: 106-123.

Ray, S. M. 1952a. A culture technique for diagnosis of infection with Dermocystidium marinum Mackin, Owen, and Collier in oysters. Science 116: 360 .

- 1952b. A culture technique for the diagnosis of infection with Dermocystidium marinum in oysters. Convention Addresses Nat. Shellfisheries Assoc. 1952: 9-13.

-- 1954a. Stulies on the occurrence of Dermocystidium marinum in young oysters. Convention Addresses Nat. Srellfisheries Assoc. 1953: 80-88.

-_- 1954b. Experimental studies on the transmission and pathogenicity of Dermocystidium marinum, a fungus disease of oysters. Jour. Parasitol. 40: 235.

-195te. Biological studies of Dermocystidium marinum, a fungus parasite of orsters. Rice Inst. Pamp. Special Issue, November 1954.

Ray, S. M. \& A. C. Chandler. 1955. Dermocystidium marinum, a parasite of oysters. Exp. Parasitol. 4: 172-200.

Ray, S. M., J. G. Mackin, \& J. L. Boswell. $195 \overline{.}$ Quantitative measurement of the effect on oysters of disease caused by Dermocystidium marinum. Bull. Mar. Sci. Gulf and Caribbean 3: 6-33.

Snedecor, G. W. 1946. Statistical methods. 4th ed. Ames: Iowa State College Press. $485 \mathrm{pp}$. 